\title{
Influence of Weather Conditions on Particulate Matter Suspension following the 2010 Eyjafjallajökull Volcanic Eruption
}

\author{
Mary K. Butwin, ${ }^{\mathrm{a}, \mathrm{b}}$ Sibylle von Löwis, ${ }^{\mathrm{b}}$ Melissa A. Pfeffer, ${ }^{\mathrm{b}}$ Pavla Dagsson-Waldhauserova, ${ }^{\mathrm{c}, \mathrm{d}}$ \\ JOHANN THORSSON, ${ }^{\mathrm{e}}$ AND THROSTUR THORSTEINSSON ${ }^{\mathrm{a}}$ \\ a Institute of Earth Sciences, University of Iceland, Reykjavík, Iceland \\ ${ }^{\mathrm{b}}$ Icelandic Meteorological Office, Reykjavík, Iceland \\ ${ }^{\mathrm{c}}$ Agricultural University of Iceland, Borgarnes, Iceland \\ ${ }^{\mathrm{d}}$ Czech University of Life Sciences Prague, Prague, Czech Republic \\ ${ }^{\mathrm{e}}$ Soil Conservation Service of Iceland, Hella, Iceland
}

(Manuscript received 7 May 2020, in final form 27 August 2020)

\begin{abstract}
The 2010 eruption of Eyjafjallajökull produced volcanic ash that was mostly deposited to the south and east of the volcano, with the thickest deposits closest to the eruption vents. For months following the eruption there were numerous reports of resuspended volcanic ash made by weather observers on the ground. A saltation sensor (SENSIT) and an optical particle counter (OPC) located on the southern side of Eyjafjallajökull measured posteruptive particulate matter (PM) saltation and suspension events, some of which were also observable by satellite imagery. During the autumn/winter following the eruption, visible satellite images and the SENSIT show that PM measured by the OPC was only detected when winds had a northerly component, making the source on the slopes of Eyjafjallajökull. During the largest observed events, particles $>10 \mu \mathrm{m}$ were suspended but measured in extremely low concentrations ( $<1$ particle per centimeter cubed). The saltation measurements, however, show high concentrations of particles $>100 \mu \mathrm{m}$ in size during these events. During the largest events, winds were at least $5 \mathrm{~m} \mathrm{~s}^{-1}$ with a relative humidity $<70 \%$. Ground conditions in Iceland change quickly from unfavorable to favorable for the suspension of particles. It is hypothesized that this is due to the porosity of the surface material allowing water to filter through quickly as well as the fast drying time of surface material. The high moisture content of the atmosphere and the ground do not appear to be a deterrent for large PM events to occur in Iceland.
\end{abstract}

KEYWORDS: Volcanoes; Aerosols; Particulates; Aerosols/particulates; Air quality and health

\section{Introduction}

The explosive stage of the 39-day-long eruption of Eyjafjallajökull started on 14 April 2010 and emitted $270 \times 10^{6} \mathrm{~m}^{3}$ of airborne tephra, with daily maximum plume heights ranging from 3 to $10 \mathrm{~km}$ (Gudmundsson et al. 2010; Stohl et al. 2011; Gudmundsson et al. 2012; Stevenson et al. 2012). Half of the airborne tephra $\left(140 \times 10^{6}\right.$ $\pm 20 \times 10^{6} \mathrm{~m}^{3}$ ) was deposited on Iceland (Gudmundsson et al. 2012). Deposits ranged from a dusting to an over 30-m-thick layer at the rims of the ice cauldrons that formed above the two main subglacial vents (Gudmundsson et al. 2012). The depth of the tephra deposits decreased rapidly with increasing distance from the vents (Fig. 1a); at $2 \mathrm{~km}$ from the vents, the depth was measured to be $1 \mathrm{~m}$ (Gudmundsson et al. 2012). At least a dusting of ash was reported everywhere in Iceland except for in the West Fjords (Gudmundsson et al. 2012). Most of the ash deposition measurements were made to the south and east of the vent, where ash deposits were initially between 1 and $15 \mathrm{~cm}$ (Fig. 1a) (Gudmundsson et al. 2012; Arnalds et al. 2013).

After the Eyjafjallajökull eruption ended on 22 May 2010, dust storms and resuspended ash events were observed frequently by

Corresponding author: Mary K. Butwin,mkb5@hi.is

Earth Interactions is published jointly by the American Meteorological Society, the American Geophysical Union, and the Association of American Geographers. weather observers throughout Iceland (Dagsson-Waldhauserova et al. 2014a; Nakashima and Dagsson-Waldhauserova 2019; Butwin et al. 2019). Both dust storms and resuspension of ash are defined here as particulate matter (PM) events (Arnalds et al. 2013). PM is composed of any solid material suspended in the atmosphere. These particles can come from pollen, sea salt, smoke, dust, and volcanic ash (AMS 2012). The length of time following an Icelandic eruption that PM events occur, that contain mostly resuspended ash as opposed to the bulk material available for dust storms, is primarily dependent on the weather conditions and secondarily on the amount of material produced by the eruption (Butwin et al. 2019). Typically, ash provided by an eruption increases the number of PM events above the background levels for less than one year (Butwin et al. 2019). However, ash can be resuspended for longer than one year but is generally accompanied by other available material, so that the PM event is not mostly composed of resuspended ash. During May 2010 most of the explosive phase of the eruption had ended, with activity restricted to the crater area. May is also the month with the most frequent PM observations in Iceland when there are dry surface conditions due to little precipitation and high winds, regardless of whether ash has recently been deposited by an eruption (Dagsson-Waldhauserova et al. 2014a; Butwin et al. 2019; Nakashima and Dagsson-Waldhauserova 2019). In 2010, southern Iceland experienced drier conditions than average, warmer temperatures, and below-average wind speeds (Petersen 2010; Icelandic Meteorological Office 2011). With the dry conditions and warm temperatures, there was also unusually little 

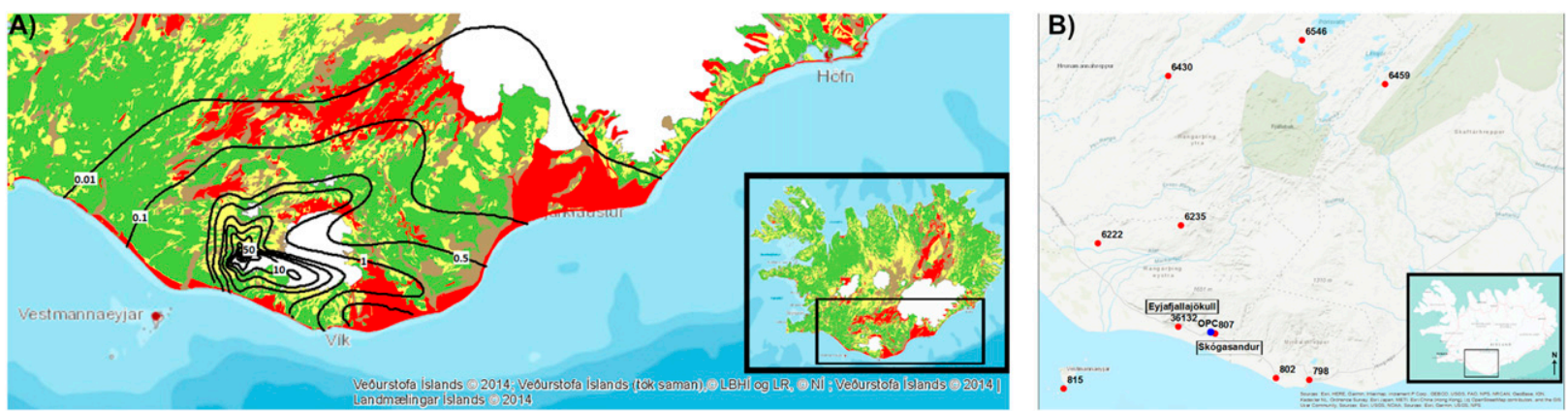

FIG. 1. (a) Isopachs of tephra thickness (cm) from Eyjafjallajökull 2010 eruption over the dust source map of Iceland. The dust source map shows areas from low erosion (green) to extreme erosion (red). (Erosion data: Agricultural University of Iceland and the Soil Conservation Service of Iceland. Basemap data: National Land Survey of Iceland. Cartography: Icelandic Meteorological Office. Isopachs are provided through the courtesy of M. T. Gudmundsson). (b) Map of weather stations (automatic, staffed, and precipitation) with station number, and OPC location (blue) in southern Iceland, as well as SENSIT located at Skógaheiði. See Table 1 for station type and exact location.

snow cover in the south, allowing PM, including the recently deposited ash, to be easily suspended despite lower-than-normal wind speeds. The PM events in June 2010 were especially strong and frequent along the south coast (Schumann et al. 2011; Leadbetter et al. 2012; Petersen et al. 2012; Thorsteinsson et al. 2012; Arnalds et al. 2013), but suspension events are also observed during wetter and calmer wind periods (Dagsson-Waldhauserova et al. 2014b, 2015).

In other regions of the world that regularly experience dust storms, such as China or the United States, the meteorological conditions that create favorable conditions are often driven by synoptic-scale systems such as the passing of cold fronts or low pressure systems (Chen et al. 2003; Lei and Wang 2014; Shepherd et al. 2016). Dust events can also be started by mesoscale weather systems such as downdrafts from thunderstorms or katabatic or foehn winds (McGowan et al. 1996; Chen et al. 2003; Lei and Wang 2014). Typical wind speeds for initiation of dust suspension occurs between 5 and $10 \mathrm{~m} \mathrm{~s}^{-1}$ at the dust source in the dust belt (McGowan et al. 1996; Song et al. 2019). In the high latitudes, dust storms occur with minimum wind speeds similar to those measured in the subtropics, however, in some locations such as Antarctica, Patagonia, Greenland, and Iceland, maximum wind speeds have been up to $150 \%$ higher than in the subtropics during dust events (Bullard et al. 2016; Kavan et al. 2018; Gassó and Torres 2019). Moreover, stronger temperature and pressure gradients between surface types can form in the high latitudes resulting in stronger local winds (Bullard et al. 2016). Additionally, relative humidity, measured at about two meters above surface, is typically not higher than $40 \%$ during the onset of large dust events outside of Iceland (Natsagdorj et al. 2002; Csavina et al. 2014).

In this study, we analyze a set of PM events following the 2010 Eyjafjallajökull eruption in southern Iceland to determine if the events were likely dominated by freshly deposited ash or by the bulk available dust, ascertain the properties of the PM events, and consider the meteorological conditions that led to them. We apply the results of this analysis to provide thresholds that can be used for forecasting ash resuspension events following future eruptions in Iceland and for regular dust suspension events. These forecasts and thresholds would be important for issuing products such as air quality and transportation alerts and/or warnings. Air quality alerts or warnings would be beneficial for health care professionals and individuals to prepare for an event that would adversely affect their respiratory health (EEA 2019). Alerts for transportation could be for both ground and air travel, in which visibility as well as engine health is a concern, especially when dealing with volcanic (Prata and Tupper 2009).

\section{Methods and data}

A mobile environmental dust monitor EDM365 (Grimm Aerosol Technik) was installed on a farm in Drangshlíðardalur near Skógar, south Iceland, in September 2010, 4 months after the end of the 2010 eruption, and it operated until 1 May 2011 (Figs. 1b and 2a). This is after the 3-month-long posteruptive period during which the ash provided by the eruption clearly increased the number of PM observations, and the number of PM events detected in Iceland by weather observers had returned to the 50-yr average (Butwin et al. 2019). The farm is approximately $15 \mathrm{~km}$ south-southeast from the eruption vents. The EDM365 is an optical particle counter (OPC) that measures particles in the size range $0.25-32 \mu \mathrm{m}$ in 31 size bins using the scattering of light to count the number of particles in each size bin over 1-min intervals. Particles $>10 \mu \mathrm{m}$ were excluded from this study because number concentrations were consistently $<1$ particle per centimeter cubed in the study period and consistently below the background concentrations threshold that was determined through this research. The OPC inlet was approximately $1.5 \mathrm{~m}$ above the ground, and a drying system was installed to reduce a bias toward particles being measured as larger than they are because of enhancement by condensation during high humidity (Grimm Aerosol Technik).

In addition, there was a SENSIT electron saltation sensor located at Skógaheiði on the southern slopes of Eyjafjallajökull to measure the saltation, or the movement of particles from the surface into the atmosphere and back to the surface. Saltation measurements were taken $10 \mathrm{~cm}$ above the surface at 1-min intervals (Figs. 2b-e). The measurement height of $10 \mathrm{~cm}$ has been found to be the ideal height for saltation of volcanic 

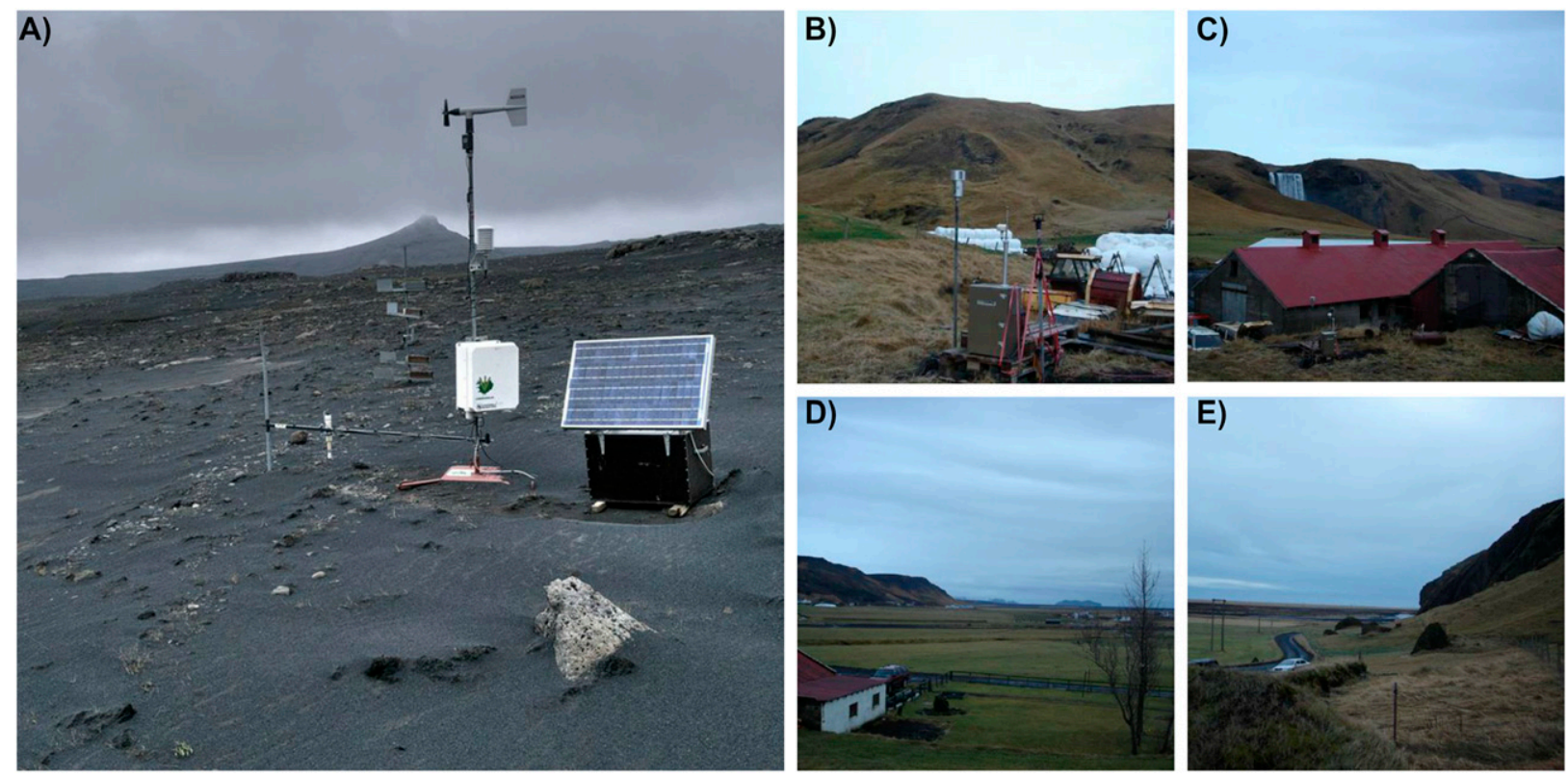

FIG. 2. (a) SENSIT saltation sensor with meteorological station in Skógaheiði (the photograph is by J. Thorsson). (b) OPC set up at the farm in Drangshlíðardalur looking northward. (c) View from the farm looking toward the northeast. (d) View to the east from the farm. (e) View to the southwest from the farm (photographs by S. von Löwis).

material in Iceland (Thorarinsdottir and Arnalds 2012; Arnalds et al. 2012). Alongside the saltation sensor was a weather station measuring wind speed and direction, temperature, and humidity every minute at a height of $2.2 \mathrm{~m}$ above the surface. This station was operational from June to November 2010. The saltation sensor uses a piezoelectric crystal to count particle impacts. For saltation counts it is unlikely that the SENSIT saltation sensor detects particles less than $50 \mu \mathrm{m}$ because it is nearly impossible for smaller grains to have enough momentum $\left(5 \times 10^{-8} \mathrm{Ns}\right)$ for the sensor to detect (Stout and Zobeck 1996; Li and Zhang 2013). For particles of $150 \mu \mathrm{m}$ in diameter wind speeds need to be approximately $11 \mathrm{~m} \mathrm{~s}^{-1}$ to achieve this momentum, which commonly occurs on the slopes of Eyjafjallajökull (Einarsson 1984; Stout and Zobeck 1996).

Weather data, including wind, precipitation, ground conditions, and relative humidity from six nearby automatic weather stations (AWS), three nearby staffed weather stations (SWS), and one staffed precipitation station, were used to assess the weather conditions down- and upwind from the OPC (Table 1, Fig. 1b). OPC measurements and reports from weather observers at SWS were used to identify PM event onset, duration, and severity; this was done through the reported weather conditions and additional remarks made by the observers. The weather station location and its spatial relationship to the OPC are important when integrating the weather data with respect to the weather's impact on PM events. The AWS Steinar (36132) operated by the Road Authority is the closest AWS to the OPC. Steinar is at the same distance from the ocean as the $\mathrm{OPC}$ is. Therefore, it provides the best representative data for atmospheric moisture content and near surface conditions $(2 \mathrm{~m}$ height) in this area. Steinar is located close to the slopes of Eyjafjallajökull and as a result frequently experiences lower

TABLE 1. Measurement sites.

\begin{tabular}{|c|c|c|c|c|c|c|}
\hline Name & Station No. & Station type & Lat & Lon & Height MSL (m) & Distance from OPC $(\mathrm{km})$ \\
\hline Drangshlíðardalur & - & OPC & $63.53^{\circ}$ & $-19.52^{\circ}$ & 36 & - \\
\hline Skógaheiði & - & SENSIT saltation and weather station & $63.56^{\circ}$ & $-19.46^{\circ}$ & 461 & 5 \\
\hline Skógar & 807 & Staffed precipitation station & $63.53^{\circ}$ & $-19.50^{\circ}$ & 36 & 1 \\
\hline Steinar & 36132 & AWS & $63.54^{\circ}$ & $-19.69^{\circ}$ & 20 & 9 \\
\hline Vatnsfell & 6546 & AWS & $64.20^{\circ}$ & $-19.05^{\circ}$ & 540 & 78 \\
\hline Tindfjöll & 6235 & AWS & $63.78^{\circ}$ & $-19.68^{\circ}$ & 870 & 29 \\
\hline Sámsstaðir & 6222 & AWS & $63.74^{\circ}$ & $-20.11^{\circ}$ & 90 & 37 \\
\hline Búrfell & 6430 & AWS & $64.12^{\circ}$ & $-19.75^{\circ}$ & 249 & 66 \\
\hline Lónakvísl & 6459 & AWS & $64.10^{\circ}$ & $-18.61^{\circ}$ & 675 & 77 \\
\hline Vatnsskarðshólar & 6045 & AWS & $63.42^{\circ}$ & $-19.18^{\circ}$ & 20 & 20 \\
\hline Vík í Mýrdal & 798 & SWS & $63.42^{\circ}$ & $-19.01^{\circ}$ & 15 & 28 \\
\hline Vatnsskarðshólar & 802 & SWS & $63.42^{\circ}$ & $-19.18^{\circ}$ & 20 & 20 \\
\hline Stórhöfði & 815 & SWS & $63.40^{\circ}$ & $-20.29^{\circ}$ & 118 & 41 \\
\hline
\end{tabular}


TABLE 2. PM event classification with comparable number and mass concentrations based on physical particle properties.

\begin{tabular}{lccrr}
\hline \hline Intensity & Total no. concentration $\left[\right.$ No. $\left.(\mathrm{cm})^{-3}\right]$ & Total mass concentration $\left(\mu \mathrm{g} \mathrm{m}^{-3}\right)$ & Particle size range $(\mu \mathrm{m})$ & Duration \\
\hline Background & $<10$ & $<10$ & $\leq 1$ & - \\
Type I & $10-100$ & $10-2200$ & - \\
Type II & $100-500$ & $2200-14000$ & $\leq 5$ & $<1$ day \\
Type III & $\geq 500$ & $\geq 14000$ & All & $\geq 1$ day \\
\hline
\end{tabular}

wind speeds than the surroundings due to being in a wind shadow, which is particularly evident when winds have some northerly components. Wind speed and direction are measured at $6 \mathrm{~m}$ height above ground instead of $10 \mathrm{~m}$ as recommended by World Meteorological Organization (WMO) at Steinar, which enhances the frictional drag of the surface. This means that wind measurements are only representative on a local scale. The other nearby weather stations are at higher elevations (stations: 6546, 6235, 6222, 6430, 6459, 815), and/or are in more open locations away from mountain sides (stations: 6546, 6235, $6222,6430,6459,6045 / 802,798,815)$, compared with the location of the OPC (Table 1). The SWS and AWS in Vatnsskaroshólar (802/6045) and the SWS in Vík (798) most likely have similar wind conditions as to where the OPC is located. These stations are set up according to WMO standards. We have analyzed multiple stations to choose the optimal weather station for analyzing the wind conditions during each PM event based on stations' proximity to the OPC as well as biases a weather station may have due to its location. Additionally, we used the full suite of nearby stations to determine the overall conditions of southern Iceland.

From 21 September 2010 to 1 May 2011, there were eight PM events reported by weather observers in Vatnsskarðshólar, Vík, and Stórhöfði (Table 2). Only six of these events were detectable in the OPC data based on number concentrations elevated above the background number concentration of 10 particles $/ \mathrm{cm}^{3}$ that is consistently present. One PM event was detected by the OPC that was not reported by any of the three weather observers in the area. The background concentration was calculated over the whole measurement period when the number concentration of PM was consistent with no changes $>$ 5 particles per centimeter cubed in the number concentration over at least three hours for all particle size bins. No PM event was reported by the SWS in the area during periods identified as background concentration. Background number concentrations were observed when the weather was cool, calm, and often cloudy, or during heavy precipitation. The size of PM events detected by the OPC were classified by relative intensity at the OPC location into categories of Type I, II, and III (Table 2), respectively. This classification does not consider the spatial expanse of the event or intensity at other locations. Type I events contain only particles of $1 \mu \mathrm{m}$ in diameter and smaller and number concentrations of 10-100 particles per centimeter cubed. Type II events last less than one day and only particles smaller than $5 \mu \mathrm{m}$ are above the background concentration with overall number concentrations of 100-500 particles per centimeter cubed. Type III events last longer than one day, particles larger than $5 \mu \mathrm{m}$ are above background concentration, and overall number concentrations are above 500 particles per centimeter cubed. These values are considerably lower than number concentrations of particles from dust sources outside of Iceland, where small dust storms would have number concentrations of at least 1000 particles per centimeter cubed (Gillies et al. 1996; Jayaratne et al. 2011; Shao and Mao 2016). Background number concentrations in areas prone to dust storms outside of Iceland are often higher than what is being classified as a Type III event here (Gillies et al. 1996; Shao and Mao 2016).

The start of a PM event is defined as when particle concentrations have exceeded 10 particles per centimeter cubed for longer than $3 \mathrm{~h}$. The end of a PM event is gradual and difficult to discern. We have defined the end of a PM event to be when number concentrations return to 10 particles per centimeter cubed for $12 \mathrm{~h}$. This accounts for temporary lulls in PM event detection by the single OPC despite an ongoing PM event due to shorter-lived changes in wind direction and/or speed. The typical particle size distribution for different size events can be seen in Fig. 3.

Three of the six events that were detected by the OPC (Table 3) were chosen for in-depth analysis. These three events were selected because in addition to detection by the OPC there were data available from weather observers and AWS, and they were categorized as Type III. Similar sized events were classified as severe wind erosion event and reported by Arnalds et al. (2013) in September 2010. Composite visible satellite images from NASA Worldview were used to supplement the surface data and to assist in determining the source area, but due to the short daylight period during wintertime their use was limited. Favorable weather conditions for Type III PM events at this location was evaluated from the weather station data and the size distributions of particles during these events were analyzed. Conditions during other PM event types are also discussed. There are additional saltation, meteorological, and grain size [Big Spring Number Eight (BSNE) wind erosion samplers] data upwind from the OPC during the October event.

\section{Results}

\section{a. 29-31 October 2010}

\section{1) SYNOPTIC SITUATION}

At the start of the dust event in southern Iceland on 29 October, there was a low pressure system to the southeast, with the $970 \mathrm{hPa}$ center over the Faroe Islands $(\sim 500 \mathrm{~km}$ away). There was also a high pressure system centered over northeast Greenland with a center pressure of $1020 \mathrm{hPa}$ approximately $2000 \mathrm{~km}$ from the south coast of Iceland. The following day, 30 October (Fig. 4a), the low pressure system 


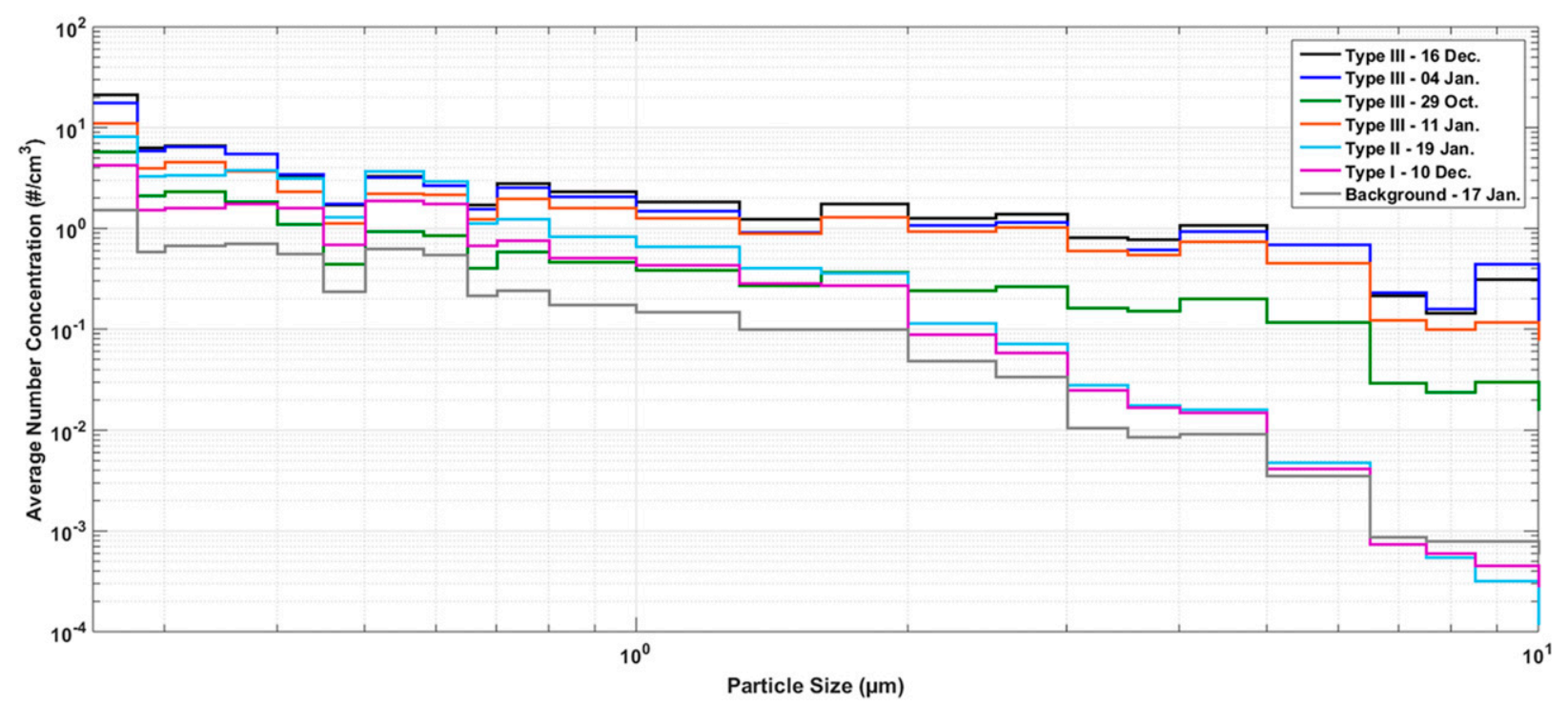

FIG. 3. Average number concentration during PM events of varying magnitudes and for background conditions.

moved north, and the center was located approximately $500 \mathrm{~km}$ to the east of Iceland. In addition, the high pressure system over northeast Greenland strengthened slightly and extended even farther south. There was also a secondary low centered $\sim 2000 \mathrm{~km}$ to the south-southeast from southern Iceland. By 31 October, the initial low and high pressure systems had moved to the north as a result of the incoming low from the southeast (Fig. 4b). With the movement of these systems, winds all over Iceland began to decrease.

\section{2) LOCAL WEATHER CONDITIONS}

In October, precipitation was measured almost every day from 1 until 19 October; after 19 October, little to no precipitation occurred (Fig. 5a). Days that did not experience precipitation still had considerable high relative humidity $(>70 \%)$ at all the examined weather stations. Following 19 October, relative humidity at all the stations fluctuated more, between $25 \%$ and $100 \%$, depending on station location and time of day (Fig. 6). This pattern is most evident at Steinar (Fig. 5b). Wind speeds after 19 October are no higher than during the earlier part of the month at each of the stations. However, during this latter part of the month there was little precipitation. These conditions resulted in multiple PM events, with the largest starting 29 October and lasting until 31 October (Fig. 5a).

The wind directions at the stations of interest were consistently northerly leading up to the PM event at the end of October at all stations except Sámsstaðir (Fig. 5c). Sámsstaðir's differing wind direction is most likely due to local effects as winds throughout Iceland were northerly. Wind speeds during the PM event were greater than $5 \mathrm{~m} \mathrm{~s}^{-1}$ at both Vatnsskarðshólar and Vík during most of the event, with only brief periods of lower wind speeds. The relative humidity at the two staffed stations is $3 \%-15 \%$ higher than what was recorded at the Steinar location possibly due to the proximity to the ocean or as a result of measurement uncertainty. Composite satellite imagery shows airborne PM originating from the slopes of Eyjafjallajökull and Mýrdalsjökull that were not at the time covered in snow (Fig. 7). Additionally, $\mathrm{PM}$ is seen originating from the sandy source area to the north and west of Eyjafjallajökull (Mælifellssandur) (Fig. 7). This suspended PM is not transported south over the mountains and is

TABLE 3. PM events observed by weather observers or detected by the OPC during the study period. See Fig. 3 for overall average particle size distribution for different events. Italicized events are discussed in detail in this paper.

\begin{tabular}{|c|c|c|c|c|c|}
\hline Start time & $\begin{array}{l}\text { Duration } \\
\text { (h) }\end{array}$ & $\begin{array}{l}\text { Wind } \\
\text { direction }\end{array}$ & $\begin{array}{l}\text { Precipitation on } \\
\text { day of event }\end{array}$ & Classification & $\begin{array}{l}\text { Weather observer } \\
\text { classification }\end{array}$ \\
\hline 1400 UTC 29 Oct 2010 & 100 & $N, N E$ & No & Tуре III & Widespread dust suspension \\
\hline 1500 UTC 10 Nov 2010 & 29 & $\mathrm{E}, \mathrm{NE}$ & No & Type III & Dust storm \\
\hline 0900 UTC 10 Dec 2011 & 36 & W & Yes & Type I & Haze \\
\hline 1415 UTC 16 Dec 2010 & 125 & $W, N, E$ & No & Type III & Dust storm, widespread dust suspension \\
\hline 0000 UTC 4 Jan 2011 & 72 & $N$ & No & Type III & $\begin{array}{l}\text { Dust storm, widespread dust suspension, } \\
\text { and whirls }\end{array}$ \\
\hline 0400 UTC 11 Jan 2011 & 84 & $\mathrm{E}$ & No & Type III & Dust storm, widespread dust suspension \\
\hline 0230 UTC 17 Jan 2011 & 24 & W & No & Background & Not observed \\
\hline 0000 UTC 19 Jan 2011 & 175 & $\mathrm{~W}, \mathrm{NW}$ & Yes & Type II & Not observed \\
\hline 1200 UTC 4 Feb 2011 & 4 & E & Yes & Background & Not observed \\
\hline
\end{tabular}



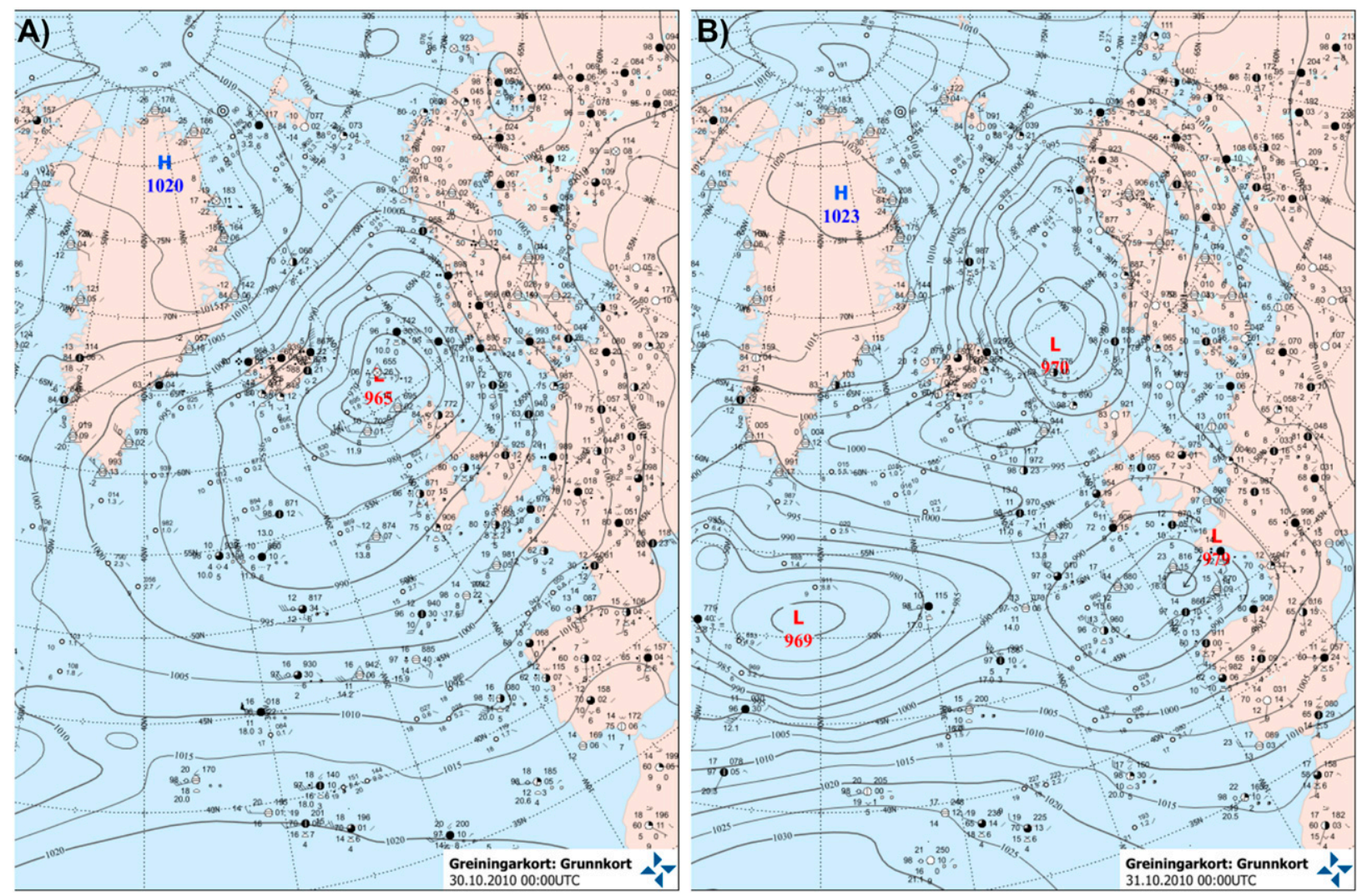

FIG. 4. Synoptic overview for the North Atlantic Ocean, valid for (a) 0000 UTC 30 Oct and (b) 0000 UTC 31 Oct 2010. Both maps are products from the Icelandic Meteorological Office.

less opaque than the PM south of Eyjafjallajökull that is measured by the OPC. By 1200 UTC 31 October, winds begin to shift to more southerly as the low pressure system moves to the north (Fig. 4b). As a result, wind directions shift to be easterly then westerly with heavy precipitation beginning after midnight, resulting in a drop in PM concentrations.
Upwind and at higher elevation than the OPC the weather station that was located with the SENSIT saltation sensor and BSNE wind erosion samplers experienced similar weather conditions as the other weather stations during the month of October (Fig. 8). Wind speeds were higher at Skógaheiði than those closer to sea level. Based on the wind directions at Skógaheiði,

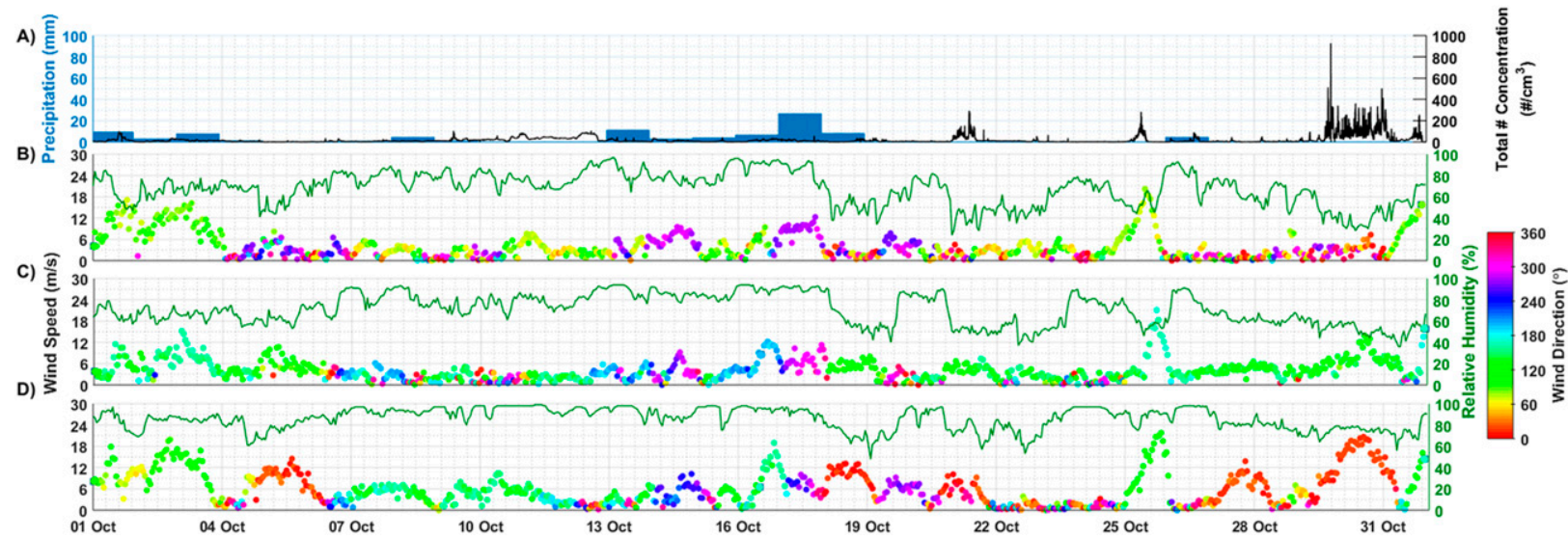

FIG. 5. October 2010 (a) precipitation (24-h sum; blue) measured at Skógar (807) and total number concentration of PM measured by the OPC (1-min sum; black line). Wind speed (left axis) and wind direction (color bar) (dots) and relative humidity (green line) measured at (b) Steinar (36132), (c) Sámsstaðir (6222), and (d) Lónakvísl (6459). 


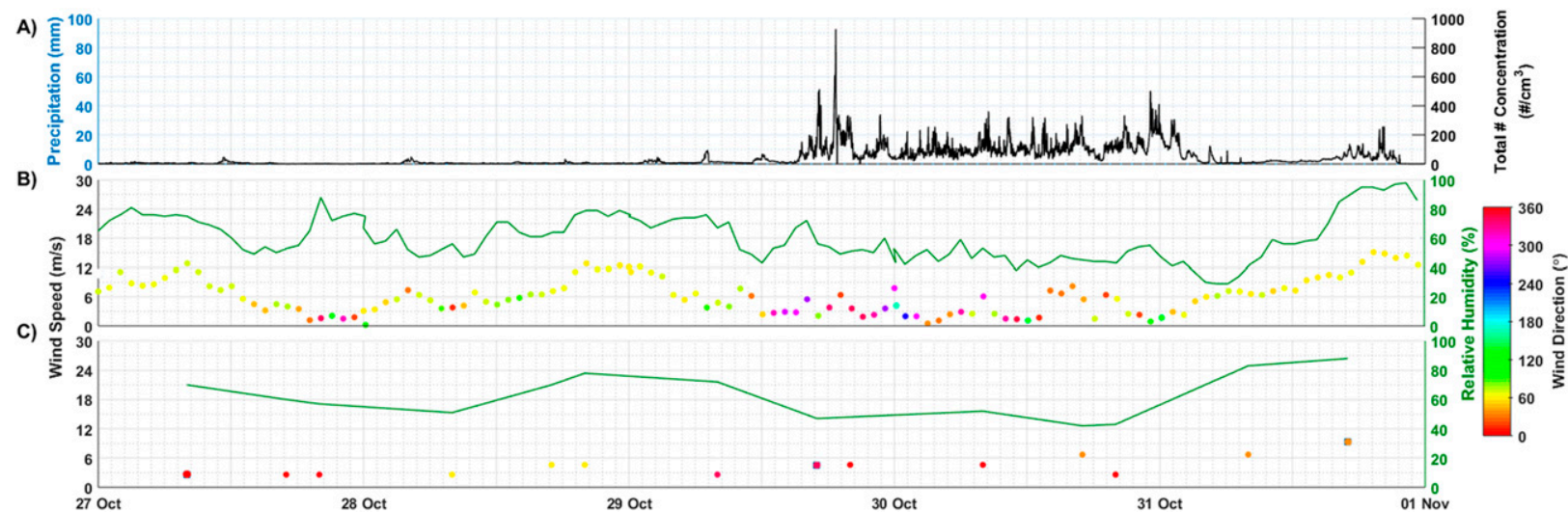

FIG. 6. Type III PM event October 2010 (a) precipitation ( $24 \mathrm{~h}$ sum; blue) measured at Skógar was $0 \mathrm{~mm}$ and therefore not seen, and total number concentration of PM measured by the OPC. Wind speed (left axis) and wind direction (color bar) (dots) and relative humidity (green line) measured at (b) Vatnsskarðshólar (6045) and (c) Vík (798).

Vatnsskaroshólar, and Steinar, it is plausible that downslope winds coming off of Eyjafjallajökull and Mýrdalsjökull were the reason for the measured PM events at the OPC location. However, on 4 and 18 October, the saltation sensor recorded events that were not measured by the OPC. During these periods, winds at Skógaheiði were $>10 \mathrm{~m} \mathrm{~s}^{-1}$, whereas at the other weather stations wind speeds were $<6 \mathrm{~m} \mathrm{~s}^{-1}$; winds at all stations were northerly at this time. Additionally, on 18 October, there was precipitation recorded at Skógar.

\section{3) PM SIZE AND CONCENTRATION}

The background particle number concentration is about 10 particles per centimeter cubed, seen both before and after the event (Fig. 9). This is typical, and number concentrations less than 10 particles per centimeter cubed can be observed during any weather conditions experienced at this site during the measurement campaign, with the lowest concentrations observed during precipitation. During the 29-31 October 2010 Type III event, the highest number concentrations were measured for particles $<1 \mu \mathrm{m}$ in diameter at which the number concentrations exceeded 80 particles per centimeter cubed, over 1-min time intervals. Particles $>1 \mu \mathrm{m}$ were also greatly enhanced during the event, mostly up to size $8.5 \mu \mathrm{m}$, where concentrations were up to 30 particles per centimeter cubed for the coarsest particles.

The OPC data show that the Type III event began at approximately 1600 UTC with particle concentrations $>100$ particles per centimeter cubed. At this time, no saltation was observed (Fig. 10) at Skógaheiði. As the event progressed saltation began and exceeded the number of particles measured by the OPC. On 30 October at approximately 1630 UTC the event began to decrease in severity and saltation of particles decreased and stopped. Meanwhile the OPC was still measuring up to 500 particles per centimeter cubed (Fig. 10).

The highest number concentrations happened at low relative humidity and winds ranging from calm to $23 \mathrm{~m} \mathrm{~s}^{-1}$ at all the weather stations; Steinar and Vatnsskarðshólar values are shown in Fig. 11.

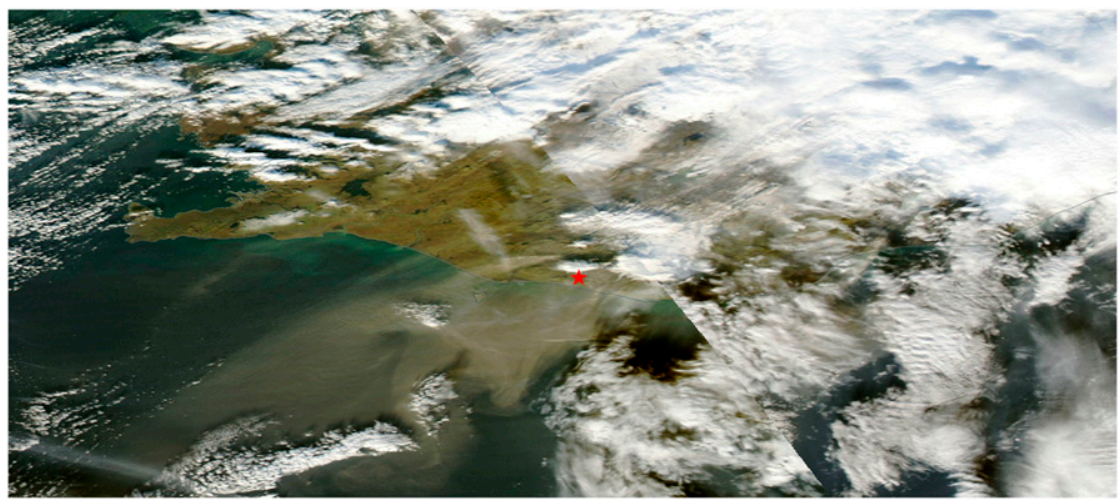

FIG. 7. Composite true color visible satellite image of southern Iceland on 30 Oct 2010. The red star represents the location of the OPC and SENSIT. Because of the scale of the image, these instruments appear to be located at the same location (the image is provided through the courtesy of NASA Worldview). 


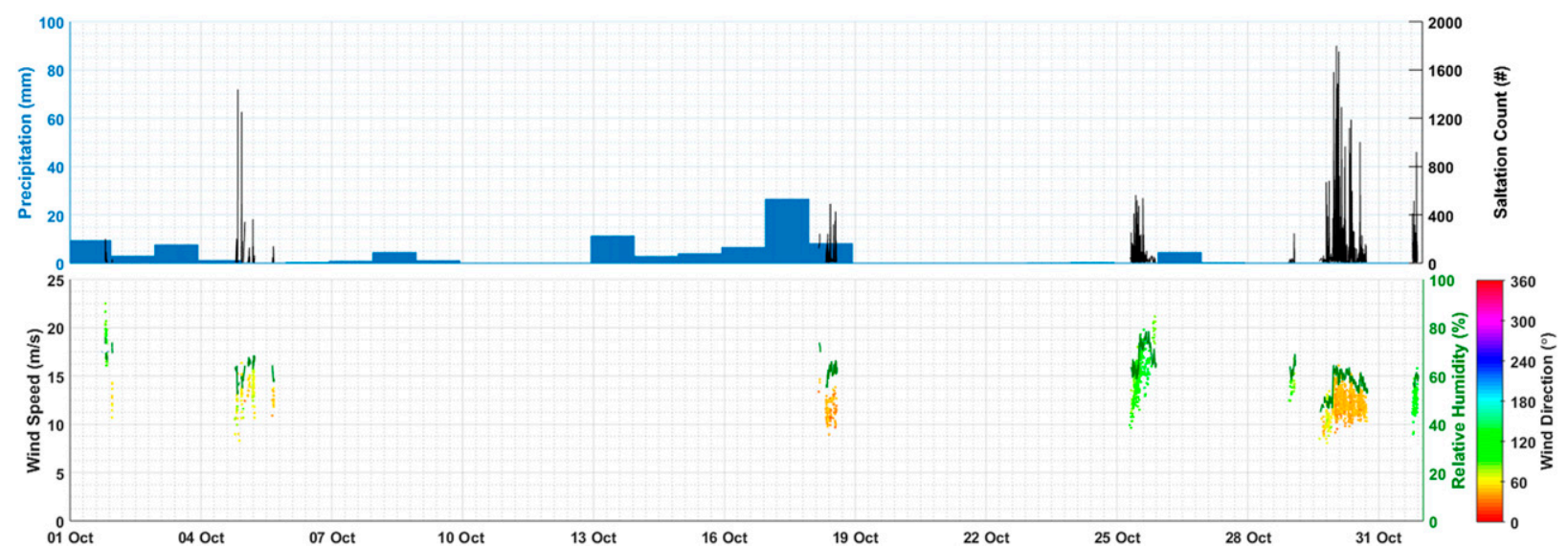

FIG. 8. October 2010 (top) precipitation (24-h sum; blue) measured at Skógar (807) and saltation count (1-min sum; black); (bottom) wind speed (left axis) and wind direction (color bar) (dots) and relative humidity (green line) measurements at Skógaheiði.

\section{4) SOURCE OF PM}

Based on the composite satellite image of 30 October 2010 (Fig. 7) and the wind directions measured at Skógaheiði (Fig. 8) the PM being measured by the OPC during this event came from the flanks of the mountain that were currently coated in ash, but typically covered in vegetation at lower elevations and solid rock at higher elevations below the ice cap edges. PM suspension is also seen originating in the persistent dust hot-spot area Mælifellssandur, north and west of Eyjafjallajökull, as seen in the satellite image (Fig. 7). This PM would contain mostly bulk Icelandic dust with a minor contribution from the 2010 ash.

\section{b. 16-23 December 2010}

\section{1) SYNOPTIC SITUATION}

During the month of December 2010, the Icelandic low was well established, with low pressure systems circling the country. On 18 December, a low pressure system moved to the northeast of Iceland, resulting in northerly winds in southern Iceland (Fig. 12a). Weather observers at SWS reported frozen surface conditions in southern Iceland without snow cover (Fig. 12b).

\section{2) LOCAL WEATHER CONDITIONS}

Precipitation at Skógar was recorded on 9-12, 15, and 24-28 December. During these periods, no PM events were measured by the OPC (Fig. 13A). During the first half of the month wind speeds were on average less than $10 \mathrm{~m} \mathrm{~s}^{-1}$ at all stations in this study and the relative humidity $>60 \%$ at stations located farther inland and at higher elevation (Búrfell, Vatnsfell, Lónakvísl). At the start of the PM event, relative humidity dropped to $\sim 60 \%$ as measured at Vatnsskaroshólar, Vík, and Steinar, and then slowly began to increase over the course of the event.

At all stations other than Lónakvísl and Sámsstaðir, wind directions throughout the month were variable because of the passing of low pressure systems. Lónakvísl predominantly experienced northerly winds, and Sámsstaðir predominantly experienced southeasterly winds. The differing wind directions at Lónakvísl and Sámsstaðir during the month of December is due to their location and relation to the of the center of low pressure systems that pass through. At the start of the PM event winds were northerly at all locations other than Steinar, which is due to the wind shadow from Eyjafjallajökull. Wind speeds during this time were varied between 8 and $24 \mathrm{~m} \mathrm{~s}^{-1}$

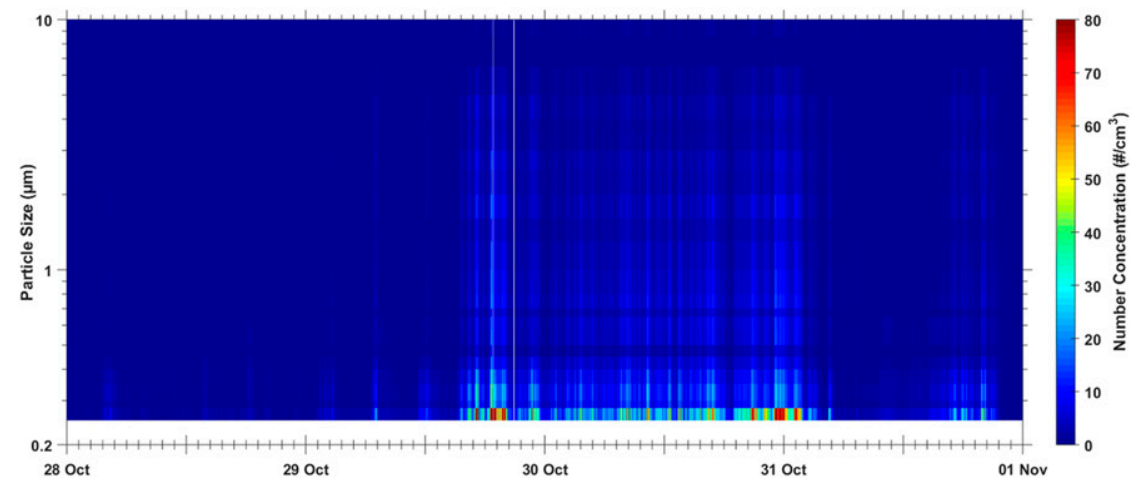

FIG. 9. Number concentration by size for the PM event at the end of October 2010. There are no data below $0.25 \mu \mathrm{m}$. 


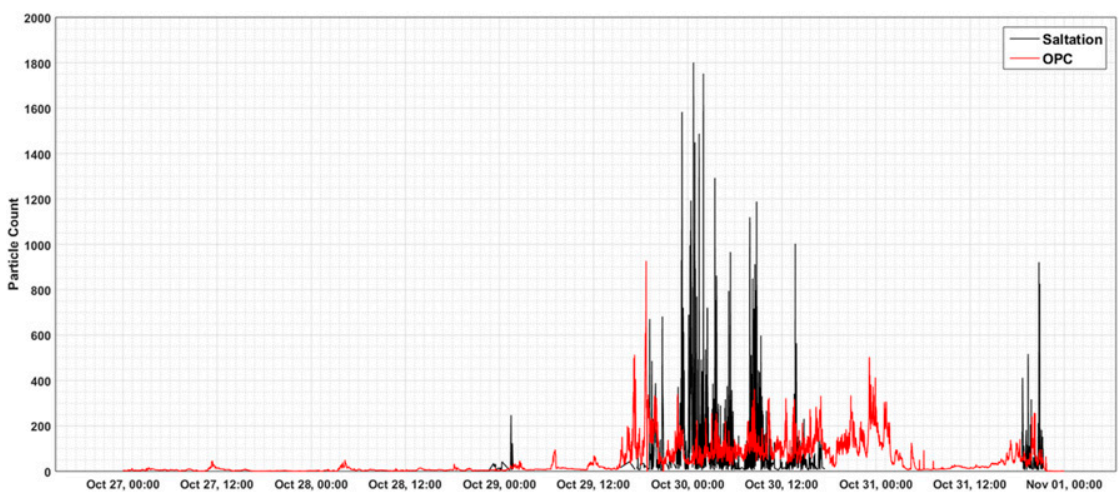

FIG. 10. Particle count as measured by SENSIT saltation sensor (No.) and the OPC (number per centimeter cubed) before and during the October Type III event.

depending on the station. The PM event ended when the wind directions shifted to southerly, the humidity rose, and precipitation began early on 24 December (Fig. 13). Weather observers noted that as soon as wind directions began to shift precipitation began, greatly decreasing the PM event.

\section{3) PM SIZE AND CONCENTRATION}

In December, the size distribution of particles during events was much more variable over time than in the other months analyzed. During dry periods, the number concentrations were above the background of 10 particles per centimeter cubed. For most of the time suspended particles were smaller than $5 \mu \mathrm{m}$, but during PM events particles of $10 \mu \mathrm{m}$ in diameter and less were measured. The highest particle number concentrations were observed for particles $1 \mu \mathrm{m}$ and less (Fig. 14). The Type III event that occurred 16-23 December had frequent peaks; every $2-10 \mathrm{~h}$. Number concentrations $>80$ particles $/ \mathrm{cm}^{3}$ were measured for particles $\leq 2.5 \mu \mathrm{m}$ during the peak of the event (Fig. 14). It was observed that the lower the humidity the higher the number concentrations regardless of the wind speed. Weather reports outside of this research area but in southern Iceland also reported numerous PM events during the period of 16-23 December.

\section{4) Source OF PM}

There were no usable satellite images during this event because of wintertime darkness. Due to the low elevation of the PM, brightness temperature differences and infrared images did also not detect the event. As a result, we use only wind directions to assess the most likely source for the lofted PM. All the weather stations in the research area measured northnorthwesterly winds during the first two days of the event, indicating that the material measured by the OPC most likely came from the sides of the mountain and not from a persistent source area, meaning the PM measured by the OPC was resuspended ash. However, on 18 December winds began to shift and become more easterly. During this time dust from the Skógasandur plain $(<10 \mathrm{~km})$ may have also been suspended. The latter part of the December 2010 PM event may have been mixed resuspended volcanic ash and bulk Icelandic dust.

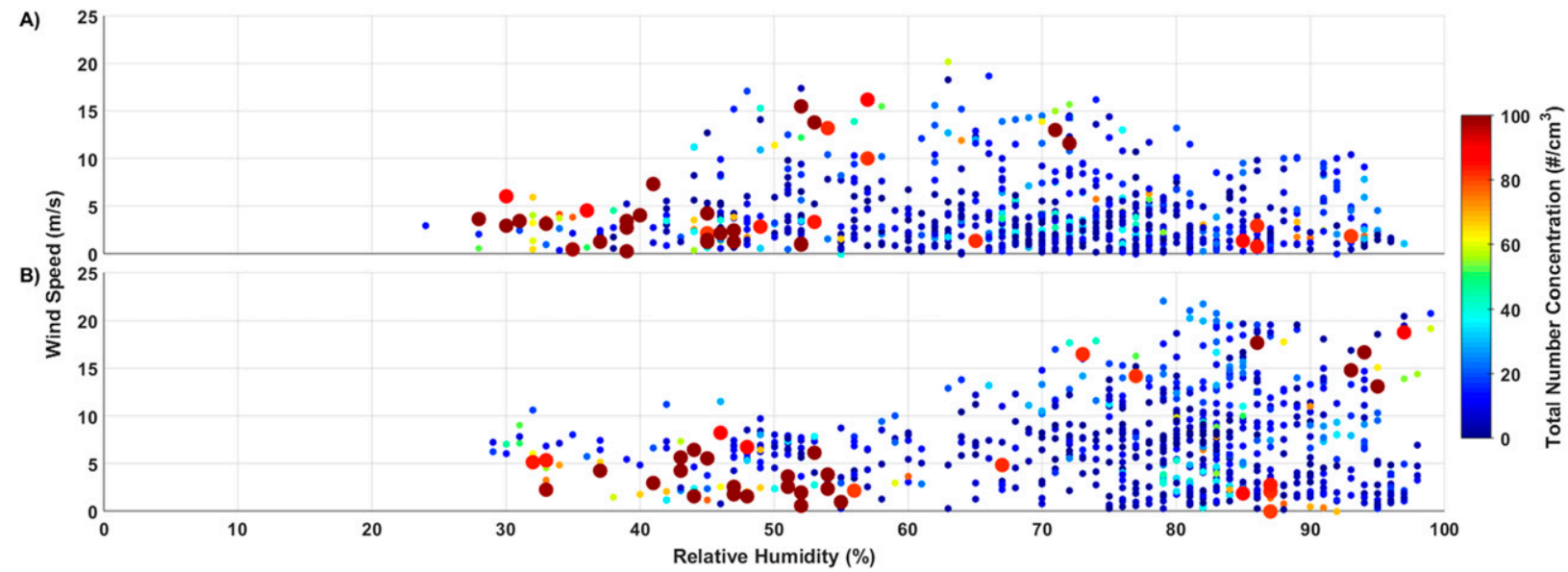

FIG. 11. Total number concentration of PM (color scale) measured by the OPC during October as a function of wind speed ( $y$ axis) and relative humidity ( $x$ axis) measured at (a) Steinar (36132) and (b) Vatnsskarðshólar (6045). 
A)

B)
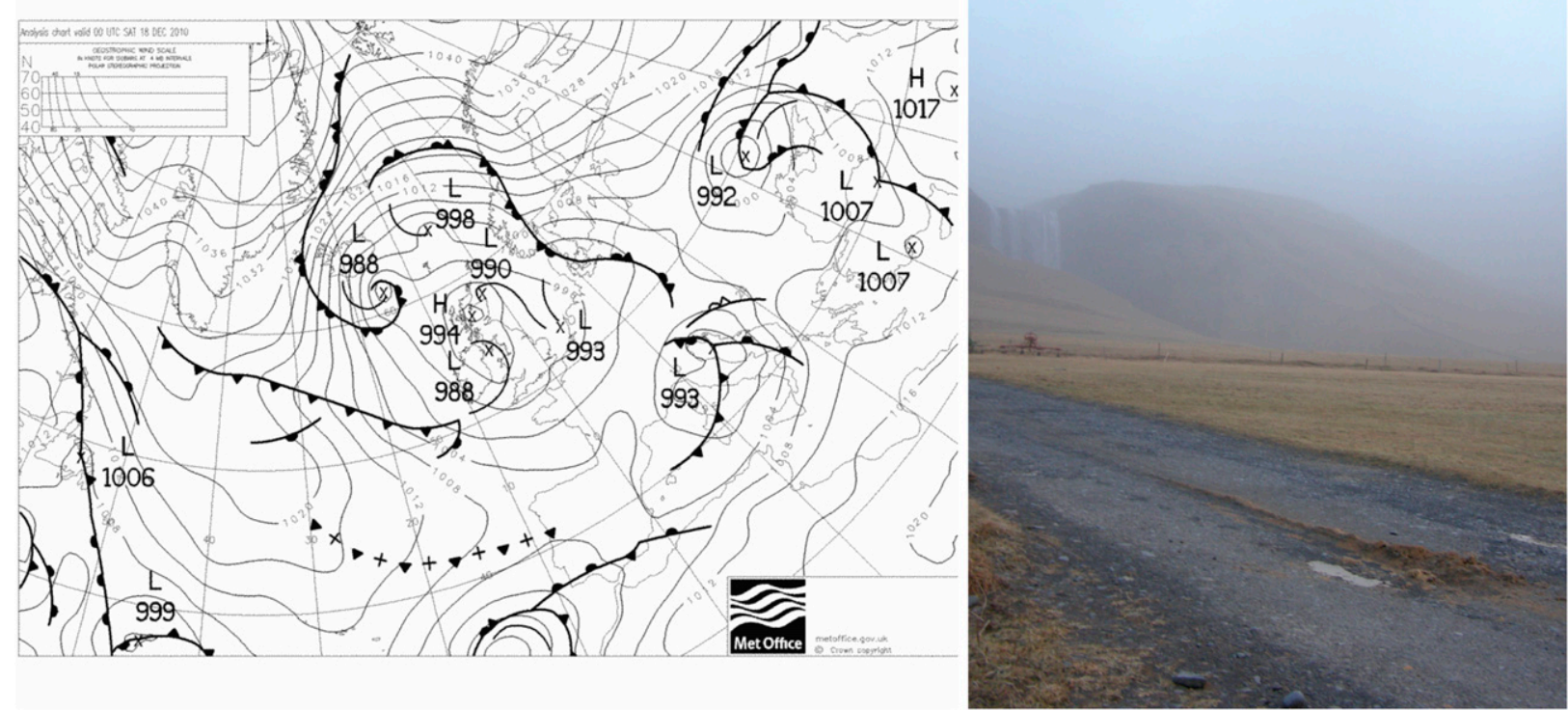

FIG. 12. (a) Synoptic-scale conditions for the North Atlantic, valid for 0000 UTC 18 Dec 2010 (the map is provided through the courtesy of the Met Office). (b) PM event looking northeast from the OPC station on 17 Dec 2010 (the image was taken by M. Jónsdóttir of Drangshlíðardalur).

\section{c. 4-8 January 2011}

\section{1) SYNOPTIC SITUATION}

The conditions at the start of January 2011 were very similar to those of December 2010, with low pressure systems either approaching Iceland from the south and then traveling to the northeast or traveling to the south of Iceland and continuing east (Fig. 15a).

\section{2) LOCAL WEATHER CONDITIONS}

The relative humidity was greater than $80 \%$ prior to and after the 4-9 January PM event (Fig. 16). During the event, the humidity dropped in all locations, with the greatest drop occurring in Vatnsskaroshólar and Steinar, which went from $>90 \%$ to $<40 \%$. After 8 January, the weather pattern remained steady and two more PM events occurred that were classified as Type II and III. Starting 15 January, humidity was once again high at all stations, and precipitation was recorded at Skógar every day that month except 23 and 26 January.

Starting 3 January, winds were consistently northerly for stations other than Sámsstaðir and Steinar. Sámsstaðir experienced more easterly winds, whereas the winds at Steinar were a fluctuation of westerly and northerly winds. This also occurred to a lesser degree at Vatnsskarðshólar. Wind speeds at Vatnsskarðshólar peaked at $29 \mathrm{~m} \mathrm{~s}^{-1}$ on 7 January during the event (Fig. 16). Steinar's wind speeds fluctuated between 2 and $20 \mathrm{~m} \mathrm{~s}^{-1}$, showing that despite the shelter of the mountain there were still intermittent strong winds close to the OPC.
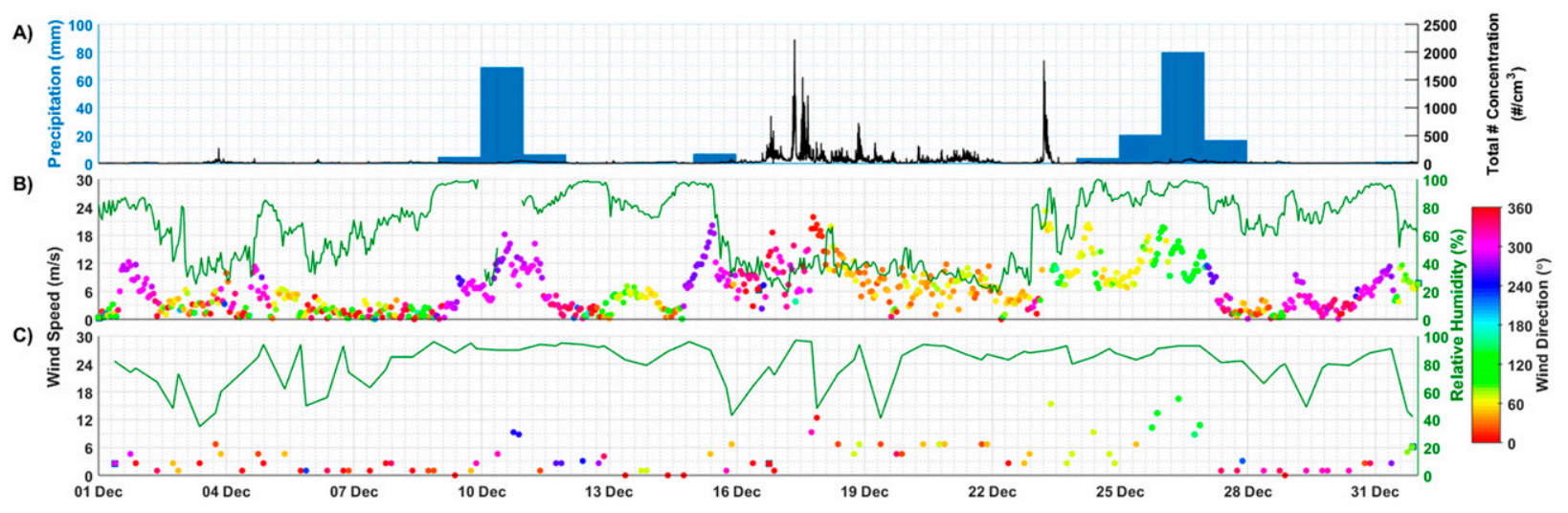

FIG. 13. (a) Precipitation (24-h sum; blue) and total number concentration of PM (1-min sum; black) during December 2010. (b) Wind speed (left axis) and wind direction (color bar) (dots) and relative humidity (green) at Vatnsskarðshólar (6045) and (c) Vík (798). 


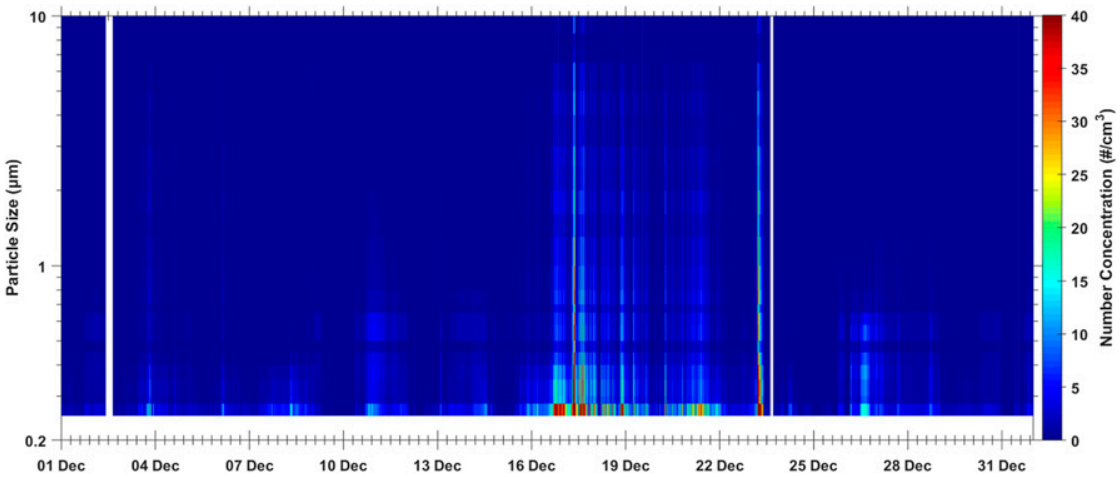

FIG. 14. Total number concentration and size distribution during the December 2010 event.

There are no data below $0.25 \mu \mathrm{m}$.

\section{3) PM CONCENTRATIONS}

Even with precipitation, number concentrations of particles were above the background of 10 particles per centimeter cubed. During the Type III event that began on 4 January there were two main peaks of particle number concentrations. The peaks in PM concentration coincide with peaks in wind speed at Vatnsskarðshólar. Following the end of the first peak in particle concentrations wind speeds decreased, and humidity rose upwind from the OPC. When wind speeds began to increase upwind from the OPC, the number concentrations began to rise once again.

During this Type III event the size distribution was very similar to the event that occurred in mid-December, except it was shorter lived (Figs. 14 and 17). Figure 16 shows the influence of precipitation before the event as the OPC was measuring well within the background levels. Figure 17 shows the number concentrations by particle sizes for the month of January. Drops in number concentration in all size bins correspond to periods of precipitation (Fig. 16).

\section{4) SOURCE OF PM}

At the start January there is enough daylight to create a composite visible satellite image that covers the south coast of
Iceland and extends just north of Eyjafjallajökull. The image produced for 5 January (Fig. 15b) shows PM coming directly off the south coast of Iceland. The dust appears to be from the slopes of Eyjafjallajökull and from the sandur plains to the east. The PM continues to move south off the coast of Iceland until about $\sim 30 \mathrm{~km}$ offshore when wind direction shifts from northerly to easterly. The measured wind directions are mostly northerly. The PM measured by the OPC during this event is most likely resuspended ash.

\section{Mass concentrations during type III events}

The European Environment Agency's (EEA) hourly health limit for $\mathrm{PM}_{10}$ is $50 \mu \mathrm{g} \mathrm{m}^{-3}$, a limit that is based on when people begin to feel the effects of PM on the respiratory system (EEA 2019). Assuming a density of $2.36 \mathrm{~g} \mathrm{~cm}^{-3}$, which was calculated by Butwin et al. (2019) for suspendable $\mathrm{PM}$ in Iceland, the mass concentrations of $\mathrm{PM}_{10}, \mathrm{PM}_{2.5}$, and $\mathrm{PM}_{1}$ were calculated for October, December, and January. During the three Type III events discussed, the $\mathrm{PM}_{10}$ concentrations at the OPC were above the hourly limit for $90 \%$ of the duration of the events, for almost $700 \mathrm{~h}(689 \mathrm{~h})$ during
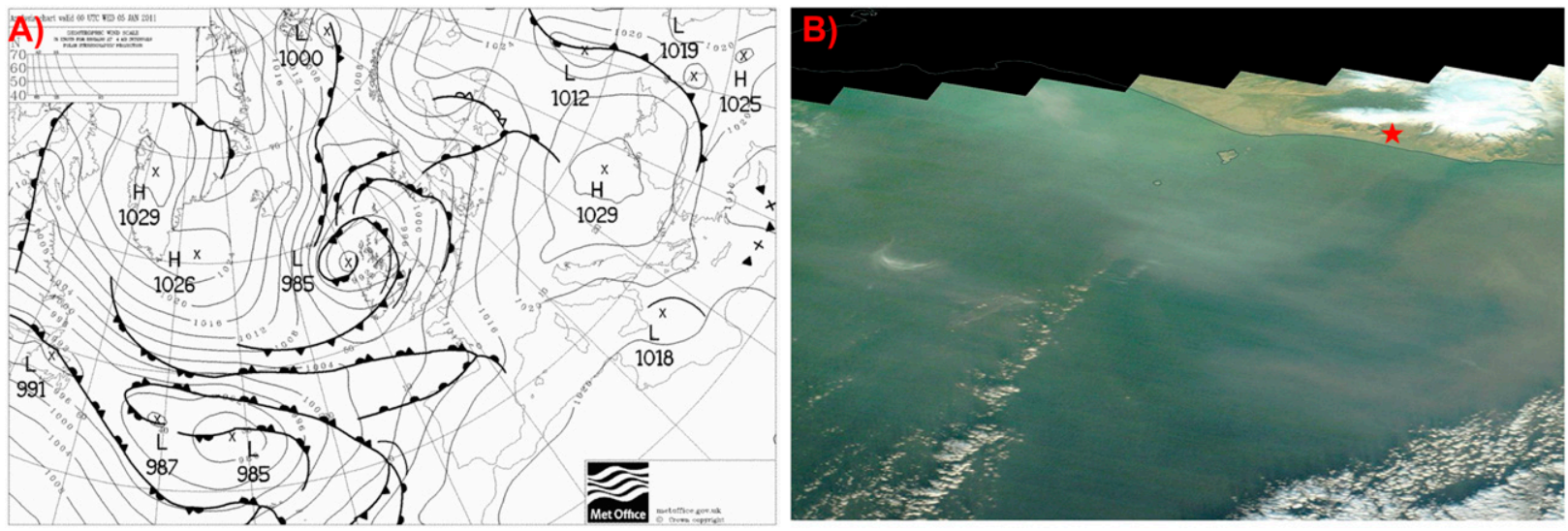

FIG. 15. (a) Synoptic-scale conditions for the North Atlantic, valid for 0000 UTC 5 Jan 2011 (the map is provided through the courtesy of the Met Office). (b) Composite true color visible satellite image of southern Iceland on 5 Jan 2011. The red star represents the location of the OPC (the image is provided through the courtesy of NASA Worldview). 


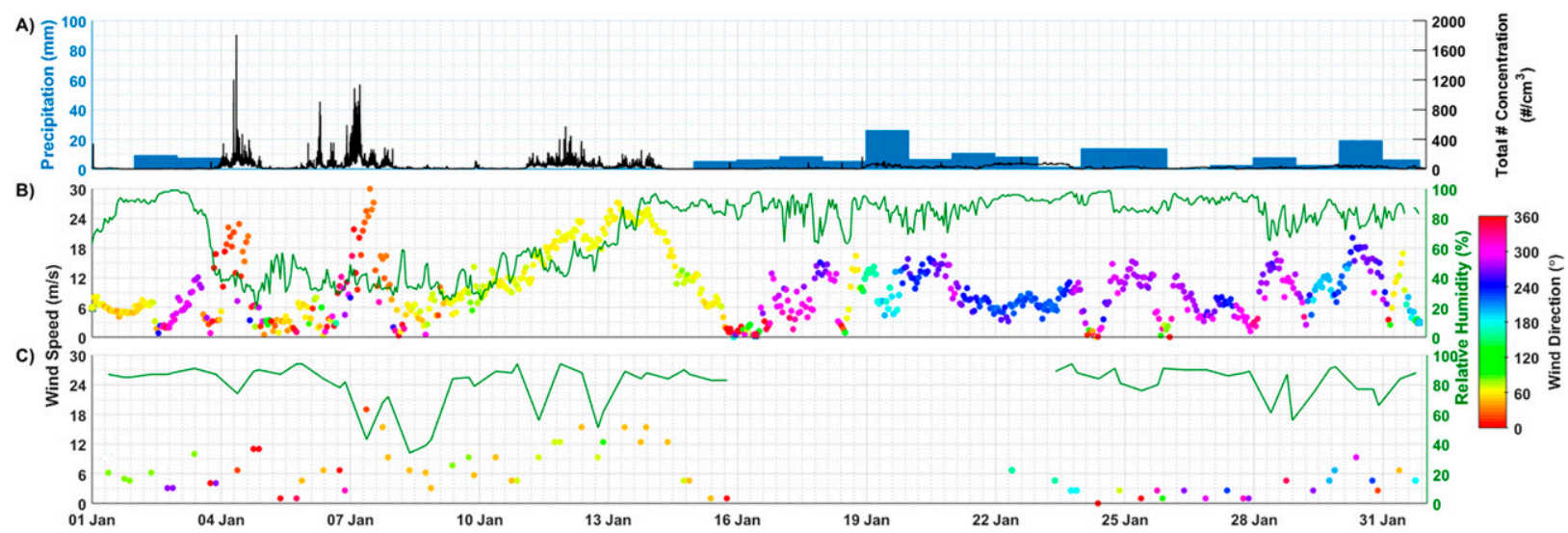

FIG. 16. Particle concentration and weather conditions for January 2011 with a PM event occurring 4-9 Jan 2011. (a) Precipitation from Skógar and total number concentration of PM recorded by the OPC. Wind speed (left axis) and wind direction (color bar) (dots) and relative humidity (green) from (b) Vatnsskarðshólar and (c) Vík. Missing data occurred 16-23 Jan at Vík.

these three months (Fig. 18). Mass concentrations during the peaks of these events were above $1000 \mu \mathrm{g} \mathrm{m}^{-3}$, with the highest hourly average mass concentration of $27200 \mu \mathrm{g} \mathrm{m}^{-3}$ measured in December (Fig. 18).

\section{Conditions during weaker PM events}

The presence of moisture becomes a stronger prohibitor of PM suspension resulting in weaker events. During the 19 January 2011 Type II event, winds were westerly and above $5 \mathrm{~ms}^{-1}$ during the time PM concentrations were above background levels. When winds dropped below $5 \mathrm{~m} \mathrm{~s}^{-1}$ so did PM concentrations.
However, wind speeds increased to $\geq 5 \mathrm{~m} \mathrm{~s}^{-1}$ within two hours, resulting in the Type II event lasting $175 \mathrm{~h}$. During this entire event relative humidity remained above $75 \%$ at all stations in the study (Fig. 16).

Type I events typically occurred in two kinds of conditions. The first being dry but calm conditions, where wind speeds are too low for PM to easily become suspended but are suspended likely due to small thermals. The second being during times of high winds and humidity $>90 \%$, including periods of precipitation. The Type I event that occurred on 10 December was one of high winds, but also high relative humidity and precipitation was recorded during the day (Fig. 13).

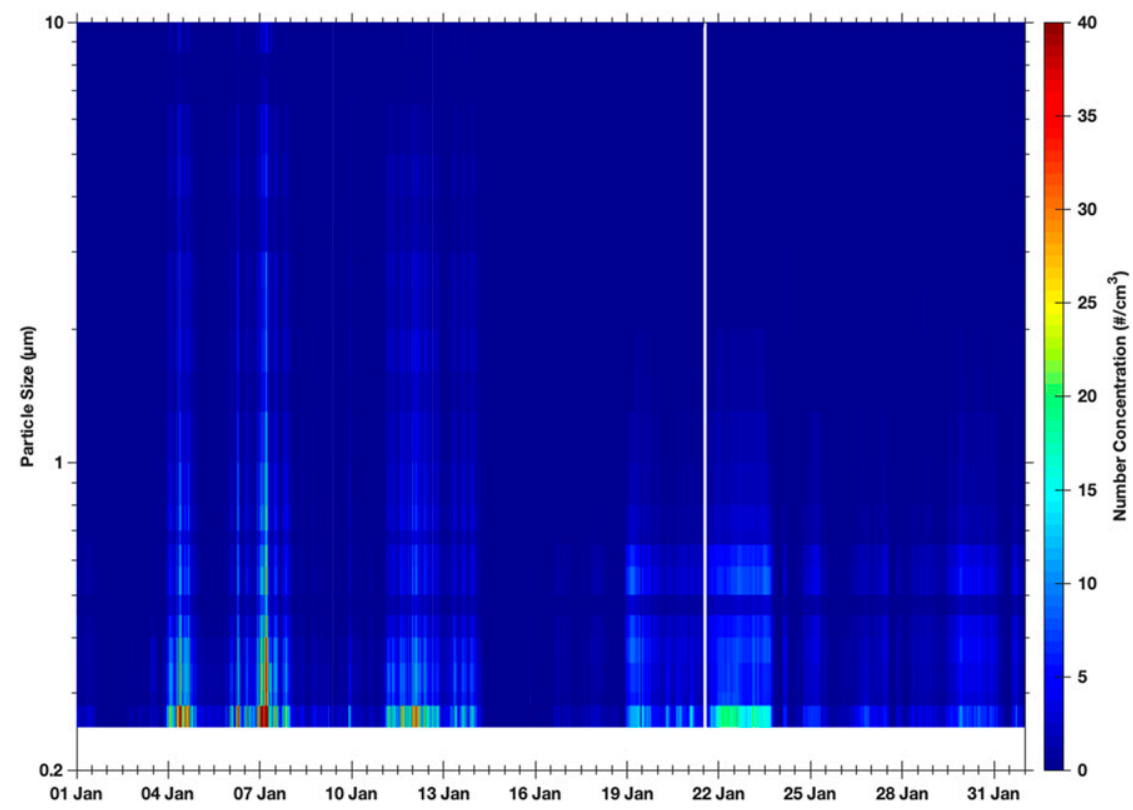

FIG. 17. Total number concentration and size distribution during January 2011. There are no data below $0.25 \mu \mathrm{m}$. 


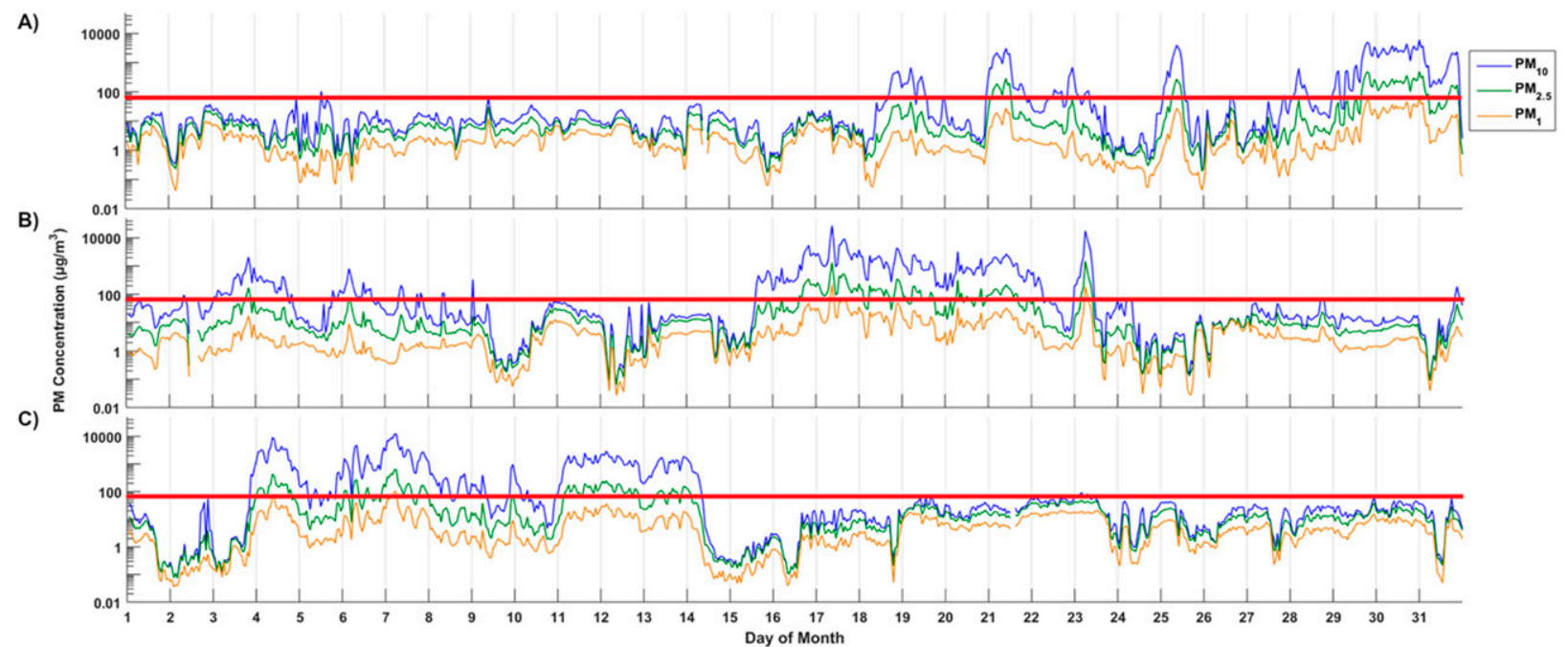

FIG. 18. Calculated mass concentrations during the months of (a) October 2010, (b) December 2010, and (c) January 2011 for $\mathrm{PM}_{10}, \mathrm{PM}_{2.5}$, and $\mathrm{PM}_{1}$. The horizontal red line represents the hourly health limit of $\mathrm{PM}_{10}$ according to the EEA.

Wind directions were north and northwesterly, with speeds $>$ $5 \mathrm{~m} \mathrm{~s}^{-1}$ at all stations.

\section{Discussion}

Based on the three Type III events that were discussed herein, the severity of the event was due primarily to the weather conditions, rather than the availability of suspendable material. Precipitation was not present during any of the largest, Type III, events examined in this study. Precipitation may have occurred as recently as one day prior as was the case in the January event (Fig. 16a). Total particle number concentrations greater than 1000 particles per centimeter cubed were typically measured when relative humidity was less than $70 \%$ and the wind direction was north to northeasterly, directly over a source, most likely the 2010 ash deposit, and toward the OPC (Figs. 13 and 16). Furthermore, dust storms were not observed in this area prior to the 2010 eruption. PM coming from the persistent dust source Mælifellssandur area would need to pass over the mountain to be measured by the OPC, which is less likely than that PM measured during north to northwesterly winds was resuspended ash that had not yet been blown or washed away or integrated into the environment. Additionally, the saltation sensor shows that coarse particles $(>50 \mu \mathrm{m})$ were moving across the surface at number concentrations $>200$ particles per centimeter cubed during a Type III event. The presence of these particles further enforces the hypothesis that these events were largely resuspended volcanic ash from the Eyjafjallajökull eruption, as this area is not normally a source of PM.

Smaller Type I and II events often occur during periods that have more moisture in the atmosphere and/or the surface (Fig. 16). Soil moisture diminishes the likelihood of particles to be suspended, resulting in lower PM concentrations of all sizes, even when strong winds went directly from a source area to the OPC. Note that the magnitude classification is based on a single measurement location. The Type I and II events may have had higher concentrations elsewhere, and had the OPC been located elsewhere, may have been classified as Type III, but this is not possible to speculate on due to the lack of other instrumentation. Classifications of events should include the spatial scale of an event, but to accomplish this, multiple measuring stations are necessary.

The PM events of this study are after the initial peak in observations following the 2010 eruption, within the time frame when the ash provided by the 2010 eruption are observed to increase the number of PM events recorded by weather observers locally (Petersen et al. 2012; Arnalds et al. 2013; Butwin et al. 2019). During the months in which the OPC was deployed, only January 2011 had more PM events than the 50-yr average number of PM events for that month considering stations near Eyjafjallajökull. Volcanic ash from the 2010 eruption was still being resuspended, without increasing the overall number of PM events in the other months, as PM from the persistent source areas was being suspended simultaneously. We speculate that the additional temporary source of the ash able to be remobilized may have increased the severity of the events until the ash was no longer available to be resuspended, but our data are insufficient to support this. Eyjafjallajökull 2010 ash deposited on the flanks of the volcano continued to be resuspended into January 2011 because of the lack of snow cover at the time. If winter 2010/11 had been a heavier snow winter, we hypothesize that the December and January events would have been dampened, or prevented entirely, by the snow.

The particle size distribution measured by the OPC during the different PM events is more dependent on weather conditions than whether the source of the material was resuspended ash or bulk dust. The size distributions of particles $<10 \mu \mathrm{m}$ measured by the OPC during the three Type III events discussed here were similar (Fig. 3) whether the source was identified as the ash deposit or a mix of ash with the bulk dust. The size distribution rather changed as a function of the severity of the event, 
depending on the environmental moistness. This coincides with the similar size distributions of particles $\leq 10 \mu \mathrm{m}$ found in volcanic ash and surface material of Iceland (Butwin et al. 2020). Because of the similar size distributions, PM source cannot be determined by $\mathrm{PM}_{10}$ size distribution alone; either wind direction or physical properties of the suspended material need to be known to identify if the material is most likely resuspended ash or bulk dust. The initial source of the PM is important for determining the potential hazards of PM events to infrastructure, transportation and health, which can differ if the material is ash or bulk dust when particles $>20 \mu \mathrm{m}$ (Horwell and Baxter 2006; Hong et al. 2010; Horwell et al. 2013; Leiva et al. 2013; Xing et al. 2016; Zhang et al. 2016; Butwin et al. 2020).

Based on saltation measurements in Skógaheiði, coarse particles $(>150 \mu \mathrm{m})$ can move across the surface (up to $150 \mathrm{~cm}$ ) during wet and windy conditions (Arnalds et al. 2013). It is hypothesized that during these moist windy conditions the surface tension on the finer grains is too great for high concentrations to become suspended in the atmosphere. Coarse particles $>2 \mathrm{~mm}$ in diameter are transported during such severe events.

With regard to moisture content, material from Iceland can be suspended under moister atmospheric conditions $(>70 \%$ relative humidity) than what is measured in other major dust sources of the world [e.g., those reported in Csavina et al. (2014)]. This finding coincides with laboratory studies done with volcanic ash from Eyjafjallajökull where suspension of grains was able to occur at all humidity levels (Del Bello et al. 2018). Additionally, the response time for surface material to dry out enough for suspension after a precipitation event is shorter than that reported outside of Iceland (Liu et al. 2004; Dagsson-Waldhauserova et al. 2014b). It is hypothesized that the reason Icelandic material is able to be suspended in moist conditions and dry out quickly following precipitation is because of its porosity and color (Richards-Thomas et al. 2020). The volcanic morphology and the unconsolidated nature of the grains allows water to easily drain. The dark color of the material will allow the surface to easily absorb heat and facilitate evaporation (Dagsson-Waldhauserova et al. 2014b; Butwin et al. 2020).

The suspension of PM in the months following the eruption of Eyjafjallajökull had similar number concentrations to events from other major dust source regions of the world; however, Iceland's were shorter in duration and more localized, as measured by the OPC (Alpert and Ganor 2001; Zhuang et al. 2001). With the frequent explosive eruptions and prime conditions for PM suspension Iceland is a major source of PM on the global scale. Because of the proximity to the Arctic the suspension of PM could have a great impact on the environment there (Arnalds et al. 2016; Meinander et al. 2016; Groot Zwaaftink et al. 2017; Kylling et al. 2018; Moroni et al. 2018; Boy et al. 2019).

\section{Conclusions}

The conditions needed for suspension of PM discussed here are comparable to those of PM suspension in other areas of the world: windy and dry, and as wind speed increases and humidity decreases, the measured particle number concentrations increase. Our results show however that PM events can occur in Iceland at higher humidity than is observed elsewhere, which may be due to surface material drying faster than in other dust source regions. We do not find a difference in weather conditions needed for resuspension of ash and suspension of other surface material. The size distribution of the resuspended volcanic ash and bulk Icelandic dust are very similar when suspended, so imagery and observations of surface conditions are key when trying to classify events as being composed of primarily resuspended volcanic ash or dust. Following future ash-producing eruptions, it is recommended to have multiple measuring stations and, as possible, sample collection. This would allow for a better constraint on how long recently deposited volcanic ash remains available for resuspension.

Northerly winds over the 2010 Eyjafjallajökull ash deposits allowed the largest PM events to be measured by the downwind OPC. These events were composed predominantly of resuspended volcanic ash. After the ash was removed from the mountainside as discussed in Butwin et al. (2019), PM events decreased at the OPC location as time passed. The exact timing for all fresh volcanic ash to be removed from bare surfaces is dependent on the weather conditions. It can be estimated that 2010 volcanic ash was being resuspended eight months after the eruption but would have been no longer distinguishable from the other loftable material by the 2-yr mark (Butwin et al. 2019). Most of the volcanic ash was removed from Skógaheiði one year after the end of the eruption.

During all measured PM events, airborne particles $<1 \mu \mathrm{m}$ have the highest number concentrations. Particle number concentrations decrease with increasing particle diameter for all measured PM events, which is opposite of what was measured directly at the dust source by Dagsson-Waldhauserova et al. (2014b).

The PM events that occurred months after the end of the Eyjafjallajökull eruption ranged in size and duration. The PM events that occurred during this time originated from the dust source areas of Iceland as well as from ash deposits from the eruption. Some of the most severe PM events recorded in Iceland that were measured occurred in the period of 2010-11, suggesting that the addition of volcanic ash increased the severity of a PM event. However, the weather conditions are what control whether a PM event will occur or not. For future eruptions, the authors stress the importance of having monitoring in multiple locations where volcanic ash can be resuspended and also having nearby weather stations. This would assist in issuing advisories at appropriate times for air quality and transportation.

Acknowledgments. The study discussed in this paper was funded through the Icelandic Research Fund Rannís Grant 152587-051. We thank Professor K. Weber and Engineer C. Fischer, University of Applied Sciences, Dusseldorf, Germany, for providing us with the OPC data and Magðalena Jónsdóttir from Drangshlíðardalur for the support of the measurements. In addition, we acknowledge the use of imagery from the NASA Worldview application (https://worldview.earthdata.nasa.gov), part of the NASA Earth Observing System Data and Information 
System (EOSDIS). The preparation of this paper was funded by the Czech Science Foundation under the HLD-CHANGE project "The Role of High Latitude Dust in Changing Climate" (2006168Y). Meteorological data are available by request through the Icelandic Meteorological Office.

\section{REFERENCES}

Alpert, P., and E. Ganor, 2001: Sahara mineral dust measurements from TOMS: Comparison to surface observations over the Middle East for the extreme dust storm, March 14-17, 1998. J. Geophys. Res., 106, 18 275-18 286, https://doi.org/10.1029/ 2000JD900366.

American Meteorological Society, 2012: Airborne particulates. Glossary of Meteorology, http://glossary.ametsoc.org/wiki/ Airborne_particulates.

Arnalds, O., F. O. Gisladottir, and B. Orradottir, 2012: Determination of aeolian transport rates of volcanic soils in Iceland. Geomorphology, 167-168, 4-12, https://doi.org/10.1016/j.geomorph.2011.10.039.

—, E. F. Thorarinsdottir, J. Thorsson, P. D. Waldhauserova, and A. M. Agustsdottir, 2013: An extreme wind erosion event of the fresh Eyjafjallajökull 2010 volcanic ash. Sci. Rep., 3, 1257, https://doi.org/10.1038/srep01257.

—, P. Dagsson-Waldhauserova, and H. Olafsson, 2016: The Icelandic volcanic aeolian environment: Processes and impactsA review. Aeolian Res., 20, 176-195, https://doi.org/10.1016/ j.aeolia.2016.01.004.

Boy, M., and Coauthors, 2019: Interactions between the atmosphere, cryosphere, and ecosystems at northern high latitudes. Atmos. Chem. Phys., 19, 2015-2061, https://doi.org/10.5194/ acp-19-2015-2019.

Bullard, J. E., and Coauthors, 2016: High-latitude dust in the Earth system. Rev. Geophys., 54, 447-485, https://doi.org/10.1002/ 2016RG000518.

Butwin, M. K., S. von Löwis, M. A. Pfeffer, and T. Thorsteinsson, 2019: The effects of volcanic eruptions on the frequency of particulate matter suspension events in Iceland. J. Aerosol Sci., 128, 99-113, https://doi.org/10.1016/j.jaerosci.2018. 12.004.

—, Pfeffer, M. A., von Löwis, S., Støren, E. W. N., Bali, E., Thorsteinsson, T., 2020: Properties of dust source material and volcanic ash in Iceland. Sedimentology, 67, 3067-3087, https:// doi.org/10.1111/sed.12734.

Chen, Y., Q. Cai, and H. Tang, 2003: Dust storm as an environmental problem in North China. Environ. Manage., 32, 413417, https://doi.org/10.1007/s00267-003-0042-1.

Csavina, J., J. Field, O. Félix, A. Y. Corral-Avitia, A. E. Sáez, and E. A. Betterton, 2014: Effect of wind speed and relative humidity on atmospheric dust concentrations in semi-arid climates. Sci. Total Environ., 487, 82-90, https://doi.org/10.1016/ j.scitotenv.2014.03.138.

Dagsson-Waldhauserova, P., O. Arnalds, and H. Olafsson, 2014a: Long-term variability of dust events in Iceland (1949-2011). Atmos. Chem. Phys., 14, 13 411-13 422, https://doi.org/10.5194/ acp-14-13411-2014.

- and Coauthors, 2014b: Physical properties of suspended dust during moist and low wind conditions in Iceland. Icel. Agric. Sci., 27, 25-39, https://doi.org/10.1.1.970.4281.

—, O. Arnalds, H. Olafsson, J. Hladil, R. Skala, T. Navratil, L. Chadimova, and O. Meinander, 2015: Snow-dust storm: Unique case study from Iceland, March 6-7, 2013. Aeolian Res., 16, 69-74, https://doi.org/10.1016/j.aeolia.2014.11.001.
Del Bello, E., J. Taddeucci, J. P. Merrison, S. Alois, J. J. Iversen, and P. Scarlato, 2018: Experimental simulations of volcanic ash resuspension by wind under the effects of atmospheric humidity. Sci. Rep., 8, 14509, https://doi.org/10.1038/s41598018-32807-2.

EEA, 2019: Air quality standards. Accessed 10 May 2019, https:// www.eea.europa.eu/themes/air/air-quality-standards.

Einarsson, M. A., 1984: Climate of Iceland. Climates of the Ocean, Elsevier, 673-697.

Gassó, S., and O. Torres, 2019: Temporal characterization of dust activity in the central Patagonia desert (years 1964-2017). J. Geophys. Res. Atmos., 124, 3417-3434, https://doi.org/ 10.1029/2018JD030209.

Gillies, J. A., W. G. Nickling, and G. H. Mctainsh, 1996: Dust concentrations and particle-size characteristics of an intense dust haze event: Inland delta region, Mali, West Africa. Atmos. Environ., 30, 1081-1090, https://doi.org/10.1016/13522310(95)00432-7.

Groot Zwaaftink, C. D., O. Arnalds, P. Dagsson-Waldhauserova, S. Eckhardt, J. M. Prospero, and A. Stohl, 2017: Temporal and spatial variability of Icelandic dust emission and atmospheric transport. Atmos. Chem. Phys., 17, 10865-10878, https:// doi.org/10.5194/acp-17-10865-2017.

Gudmundsson, M. T., and Coauthors, 2010: The April 2010 eruption of the ice-capped Eyjafjallajökull, south Iceland. Geophysical Research Abstracts, Vol. 12, Abstract EGU2010-15733, https:// meetingorganizer.copernicus.org/EGU2010/EGU2010-15733.pdf.

— , and Coauthors, 2012: Ash generation and distribution from the April-May 2010 eruption of Eyjafjallajökull, Iceland. Sci. Rep., 2, 572, https://doi.org/10.1038/srep00572.

Hong, Y.-C., and Coauthors, 2010: Asian dust storm and pulmonary function of school children in Seoul. Sci. Total Environ., 408, 754-759, https://doi.org/10.1016/j.scitotenv.2009.11.015.

Horwell, C. J., and P. J. Baxter, 2006: The respiratory health hazards of volcanic ash: A review for volcanic risk mitigation. Bull. Volcanol., 69, 1-24, https://doi.org/10.1007/s00445-006-0052-y.

_ , and Coauthors, 2013: Physicochemical and toxicological profiling of ash from the 2010 and 2011 eruptions of Eyjafjallajökull and Grímsvötn volcanoes, Iceland using a rapid respiratory hazard assessment protocol. Environ. Res., 127, 63-73, https:// doi.org/10.1016/j.envres.2013.08.011.

Icelandic Meteorological Office, 2011: The weather in Iceland 2010: Climate summary. Icelandic Meteorological Office Doc., 8 pp., http://en.vedur.is/media/vedurstofan/utgafa/skylduskil/ved-eng2010.pdf.

Jayaratne, E. R., G. R. Johnson, P. McGarry, H. C. Cheung, and L. Morawska, 2011: Characteristics of airborne ultrafine and coarse particles during the Australian dust storm of 23 September 2009. Atmos. Environ., 45, 3996-4001, https://doi.org/10.1016/ j.atmosenv.2011.04.059.

Kavan, J., P. Dagsson-Waldhauserova, J. B. Renard, K. Laska, and K. Ambrozova, 2018: Aerosol concentrations in relationship to local atmospheric conditions on James Ross Island, Antarctica. Front. Earth Sci., 6, 207-223, https://doi.org/10.3389/feart.2018.00207.

Kylling, A., C. D. Groot Zwaaftink, and A. Stohl, 2018: Mineral dust instantaneous radiative forcing in the Arctic. Geophys. Res. Lett., 45, 4290-4298, https://doi.org/10.1029/2018GL077346.

Leadbetter, S. J., M. C. Hort, S. von Löwis, K. Weber, and C. S. Witham, 2012: Modeling the resuspension of ash deposited during the eruption of Eyjafjallajökull in spring 2010. J. Geophys. Res., 117, D00U10, https://doi.org/10.1029/2011JD016802.

Lei, H., and J. X. L. Wang, 2014: Observed characteristics of dust storm events over the western United States using meteorological, 
satellite, and air quality measurements. Atmos. Chem. Phys., 14, 7847-7857, https://doi.org/10.5194/acp-14-7847-2014.

Leiva, G. M. A., D. A. Santibañez, E. S. Ibarra, C. P. Matus, and R. Seguel, 2013: A five-year study of particulate matter (PM2.5) and cerebrovascular diseases. Environ. Pollut., 181, 1-6, https://doi.org/10.1016/j.envpol.2013.05.057.

Li, X., and H. S. Zhang, 2013: Size distributions of mineral aerosols and dust emission flux observed over Horqin sandy land area in northern China. Atmos. Chem. Phys. Discuss., 13, 26712693, https://doi.org/10.5194/acpd-13-2671-2013.

Liu, X., Z. Yin, X. Zhang, and X. Yang, 2004: Analyses of the spring dust storm frequency of northern China in relation to antecedent and concurrent wind, precipitation, vegetation, and soil moisture conditions. J. Geophys. Res., 109, D16210, https://doi.org/10.1029/2004JD004615.

McGowan, H. A., A. P. Sturman, and I. F. Owens, 1996: Aeolian dust transport and deposition by foehn winds in an alpine environment, Lake Tekapo, New Zealand. Geomorphology, 15, 135-146, https://doi.org/10.1016/0169-555X(95)00123-M.

Meinander, O., P. Dagsson-Waldhauserova, and O. Arnalds, 2016: Icelandic volcanic dust can have a significant influence on the cryosphere in Greenland and elsewhere. Polar Res., 35, 31313, https://doi.org/10.3402/polar.v35.31313.

Moroni, B., O. Arnalds, P. Dagsson-Waldhauserová, S. Crocchianti, R. Vivani, and D. Cappelletti, 2018: Mineralogical and chemical records of Icelandic dust sources upon Ny-Ålesund (Svalbard Islands). Front. Earth Sci., 6, 187-219, https://doi.org/10.3389/ feart.2018.00187.

Nakashima, M., and P. Dagsson-Waldhauserova, 2019: A 60 year examination of dust day activity and its contributing factors from ten Icelandic weather stations from 1950 to 2009. Front. Earth Sci., 6, 245-253, https://doi.org/10.3389/feart.2018.00245.

Natsagdorj, L., D. Jugder, and Y. S. Chung, 2002: Analysis of dust storms observed in Mongolia during 1937-1999. Atmos. Environ., 37, 1401-1411, https://doi.org/10.1016/S13522310(02)01023-3.

Petersen, G. N., 2010: A short meteorological overview of the Eyjafjallajökull eruption 14 April-23 May 2010. Weather, 65, 203-207, https://doi.org/10.1002/wea.634.

- , H. Bjornsson, and P. Arason, 2012: The impact of the atmosphere on the Eyjafjallajökull 2010 eruption plume. J. Geophys. Res., 117, D00U07, https://doi.org/10.1029/2011JD016762.

Prata, A. J., and A. Tupper, 2009: Aviation hazards from volcanoes: The state of the science. Nat. Hazards, 51, 239-244, https://doi.org/10.1007/s11069-009-9415-y.

Richards-Thomas, T., C. McKenna-Neuman, and I. Power, 2020: Particle-scale characterization of volcaniclastic dust sources within Iceland. Sedimentoloy, https://doi.org/10.1111/sed.12821, in press.

Schumann, U., and Coauthors, 2011: Airborne observations of the Eyjafjalla volcano ash cloud over Europe during air space closure in April and May 2010. Atmos. Chem. Phys., 11, 22452279, https://doi.org/10.5194/acp-11-2245-2011.

Shao, J., and J. Mao, 2016: Dust particle size distributions during spring in Yinchuan, China. Adv. Meteor., 2016, 1-8, https:// doi.org/10.1155/2016/6940502.

Shepherd, G., and Coauthors, 2016: Global assessment of sand and dust storms. United Nations Environment Programme Rep., $123 \mathrm{pp}$.

Song, P., J. Fei, C. Li, X. Huang, P. Song, J. Fei, and X. Huang, 2019: Simulation of an Asian dust storm event in May 2017. Atmosphere, 10, 135, https://doi.org/10.3390/atmos10030135.

Stevenson, J. A., and Coauthors, 2012: Distal deposition of tephra from the Eyjafjallajökull 2010 summit eruption. J. Geophys. Res. Solid Earth, 117, B00C10, https://doi.org/10.1029/2011JB008904.

Stohl, A., and Coauthors, 2011: Determination of time- and heightresolved volcanic ash emissions and their use for quantitative ash dispersion modeling: The 2010 Eyjafjallajökull eruption. Atmos. Chem. Phys., 11, 4333-4351, https://doi.org/10.5194/ acp-11-4333-2011.

Stout, J. E., and T. M. Zobeck, 1996: Establishing the threshold condition for soil movement in wind-eroding fields. Proc. Int. Conf. on Air Pollution from Agricultural Operations, Ames, IA, Iowa State University, 65-71.

Thorarinsdottir, E. F., and O. Arnalds, 2012: Wind erosion of volcanic materials in the Hekla area, south Iceland. Aeolian Res., 4, 39-50, https://doi.org/10.1016/j.aeolia.2011.12.006.

Thorsteinsson, T., T. Jóhannsson, A. Stohl, and N. I. Kristiansen, 2012: High levels of particulate matter in Iceland due to direct ash emissions by the Eyjafjallajökull eruption and resuspension of deposited ash. J. Geophys. Res. Solid Earth, 117, B00C05, https://doi.org/10.1029/2011JB008756.

Xing, Y.-F., Y.-H. Xu, M.-H. Shi, and Y.-X. Lian, 2016: The impact of PM2.5 on the human respiratory system. J. Thorac. Dis., $\mathbf{8}$, E69-E74, https://doi.org/10.3978/j.issn.2072-1439.2016.01.19.

Zhang, T., B. Gao, Z. Zhou, and Y. Chang, 2016: The movement and deposition of PM2.5 in the upper respiratory tract for the patients with heart failure: An elementary CFD study. Biomed. Eng. Online, 15, 138, https://doi.org/10.1186/s12938-016-0281-z.

Zhuang, G., J. Guo, H. Yuan, and C. Zhao, 2001: The compositions, sources, and size distribution of the dust storm from China in spring of 2000 and its impact on the global environment. Chin. Sci. Bull., 46, 895-900, https://doi.org/10.1007/ BF02900460. 